\title{
A solution for future designs using techniques from vernacular architecture in southern Iran
}

\author{
Fatima Mirahmadi ${ }^{1}$ and Hasim Altan ${ }^{2, *}$ \\ ${ }^{1}$ Sustainable Design of the Built Environment, Faculty of Engineering \& IT, British University in Dubai, Dubai, UAE \\ 2 Architectural Engineering Department, College of Engineering, University of Sharjah, Sharjah, UAE
}

Received: 1 April 2016 / Accepted: 31 July 2017

\begin{abstract}
Nowadays in modern life, every technology and technique for comfortable life is available. People with low income, in other words, with low levels of economic power, can also have those facilities to stay warm in winter and stay cool in summer. Many years back when there were no advanced systems for human needs, passive strategies played a big role in peoples' lives. This paper concentrates on a small city in Iran that had used special strategies to solve peoples' environmental issues. The city is called Evaz, which is located in the Fars region of Iran with distance around $20 \mathrm{~km}$ from Gerash city and $370 \mathrm{~km}$ from south east of Shiraz. Evaz receives minimum rainfall, which is the reason why water is limited in this area and therefore, cisterns (water storage) had been used for many years that is studied in more detail in this paper. In summers, the climate is hot and dry, sometimes the external temperatures reaching around $46^{\circ} \mathrm{C}$ during the day. Although the winters are typically cold and likewise dry, moderate climate is available in Evaz during autumn and spring. This study identifies some of the past strategies and describes them in detail with analysis for transformation and connections with the modern and traditional fundamentals. Furthermore, the study develops some solutions utilizing a combination of both modern and traditional techniques in design to suggest better and more effective ways to save energy, and at the same time to remain sustainable for the future.
\end{abstract}

Keywords: sustainable development / vernacular architecture / passive strategies / traditional techniques / modern solutions / Iran

\section{Introduction}

Nowadays in modern life, every technology and technique for comfortable life is available. People with low-income levels or economic power can also have those facilities to stay warm in winter and stay cool in summer. Many years back when there were no modernized systems for human needs, passive strategies played a big role in peoples' life at the time. This paper focuses on a small city in Iran where vernacular architecture had played a key role for sustaining certain needs in life for people through special strategies that have been used to solve people's environmental and architectural issues, not only during those days but also even until today. The city is called Evaz and located in the Fars region of Iran with distance about $20 \mathrm{~km}$ from Gerash city and $370 \mathrm{~km}$ from south east of Shiraz. Evaz receives minimum rainfall, which is the reason why water is restricted in this area, and traditionally, vernacular architecture provided solution for many years [1-5]. Therefore, cisterns (water storage) are used and the focus of this study is in more detail on this element in this paper.

\footnotetext{
* e-mails: hasimaltan@gmail.com,

fatima.mirahmadi@gmail.com
}

The reason of selecting Evaz is the special climate and urban criteria this city has, which is extremely challenging for urban planners, architects and designers in general, and for addressing sustainability issues for the future. This city has a very limited resource, such as drinking water and electricity power. These issues have generated another sociability issue; many of residents migrated to different cities and are out of the country. The study identifies the architectural strategies of vernacular architecture in Evaz in order to generate ideas for transformation plus connections with the modern and traditional fundamentals. Furthermore, the study aims to develop some solutions utilizing a combination from modern and traditional designs in order to suggest better and more useful ways to save energy, and at the same time, sustainable design performance.

\section{Methodology}

The methodology used in this study integrates both approaches of quantitative and qualitative methods. Intensive literature review has been carried out to identify as much information as possible from existing literature. 


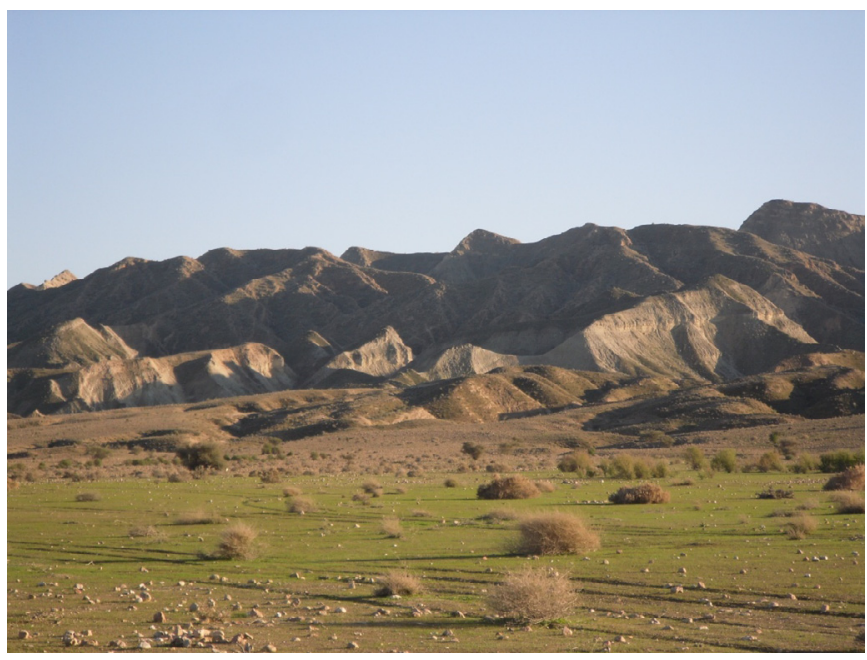

Fig. 1. Evaz plain in March 2011.

To collect further information at local level, field studies were undertaken involving interviews with local people and data collection through observation. Taking photographs of current situation in the city of Evaz, involving cultural personalities of Evaz for their consultancy and online questionnaires with Evazi people are some of the other methods such as surveys and social communications used in the study to further enhance the study and the investigation intended on the vernacular techniques of Evaz.

\section{The City of Evaz}

Evaz sites at $54^{\circ}$ southeast, $53^{\prime}$ east longitude, north latitude and longitude from Greenwich meridian, $27^{\circ} 34^{\prime}$. It receives minimum rainfall, which is the reason why water is restricted in this area [6]. In summers, the climate is hot and dry, sometimes temperatures reaching around $46^{\circ} \mathrm{C}$ during the day. Although the winters are typically cold and likewise dry, moderate climate is available in Evaz during autumn and spring.

From the climatic conditions, the area's climate is hot and dry, with average rainfall of $220-180 \mathrm{~mm}$ per year, which is more influenced by the Mediterranean air masses in autumn and winter. Maximum temperature 48-46 degrees for the months of July and August, and a minimum temperature of zero degrees, is related to the months of December and January. There is limited agricultural area in this city, the famous tree and landscape includes citrus trees, palm trees and planting vegetables. The average relative humidity of this area is maximum $58 \%$ and minimum 29\%. The number of frost days; 51 days has been reported [6] (Fig. 1). The most important reason behind this is the lack of water resources, extreme heat, irregular rainfall annually, and cheap lands.

The city's population is around 23000 people $[7,8]$. On holidays and summers, it increases because a considerable amount of Evazi people has shifted to other cities and countries around Persian Gulf and overseas. Evazi people who has immigrated to Persian Gulf's countries, usually they consider a part of their income to help their hometown especially for the places, such as construction

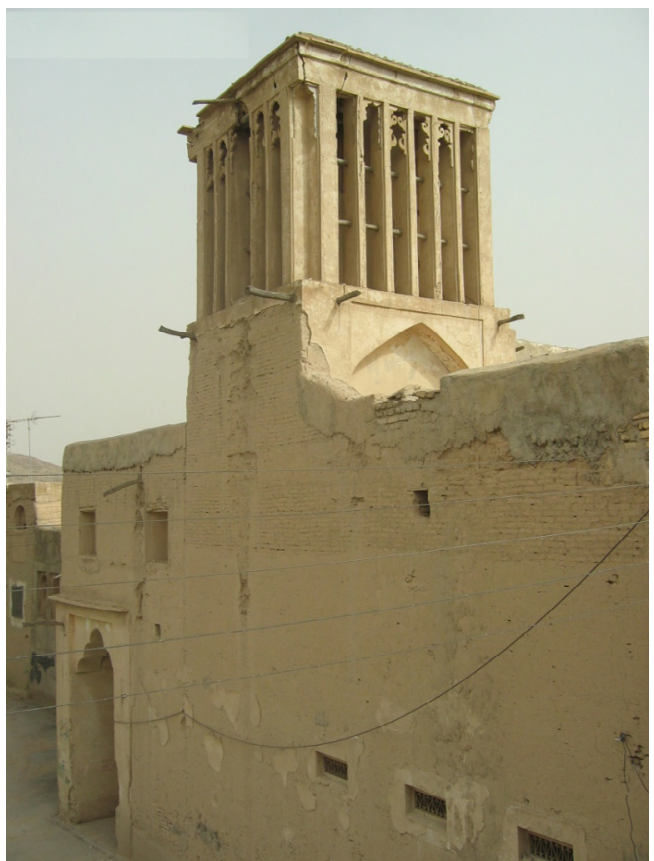

Fig. 2. Wind tower in a historic house in Evaz in November 2010.

areas, hospitals, schools and universities. At present, a considerable number of those who were living abroad have even returned to Evaz and some of them were invested their income for further development of the city.

\section{Architecture of Evaz}

History of Evaz goes back to pre-Islam era [6]. In terms of the important factors of formation of the Architecture in south of Iran and Evaz, different buildings have been constructed, old/vernacular architecture have focused on important factors such as climate and weather for each area. Observing these factors causes the influence of comfort ability and comforting in the space with balance and beauty that is the reason how they became center of the attention. To reduce the heat, the built environment was using different methods through passive strategies $[10,11]$. In Iran, Evaz is also included in hot and dry climatic conditions, and therefore the buildings were designed in a way of narrow streets and winding, high walls for houses to decrease direct sun light and to assist with shading [12].

Forms of monuments were two types introverted or extroverted. Introverted is noun for houses with yards inside the building and Extroverted is the building, which looks like cage and yard is designed out of it [13]. In order to provide a good atmosphere in warm and cold seasons, the methods that has been used by architecture of this region also included, under the ground in homes and mosques, with double shell roofs while selecting suitable materials, such as mud and brick are some of the other principles to keep the houses warm during winter [12].

Wind tower is one of the developed factors of Iranian architecture; it has a huge usage in hot, humid and dry areas. Wind tower is used especially on the top of the houses to direct the airflow into the space to create a fresh 


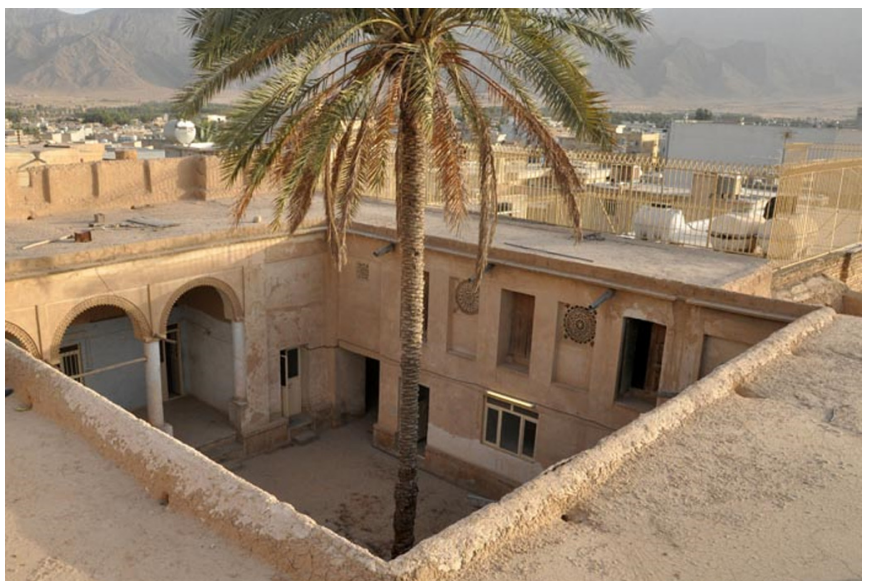

Fig. 3. Courtyard from the top view, Alipour house, in south of Iran [42].

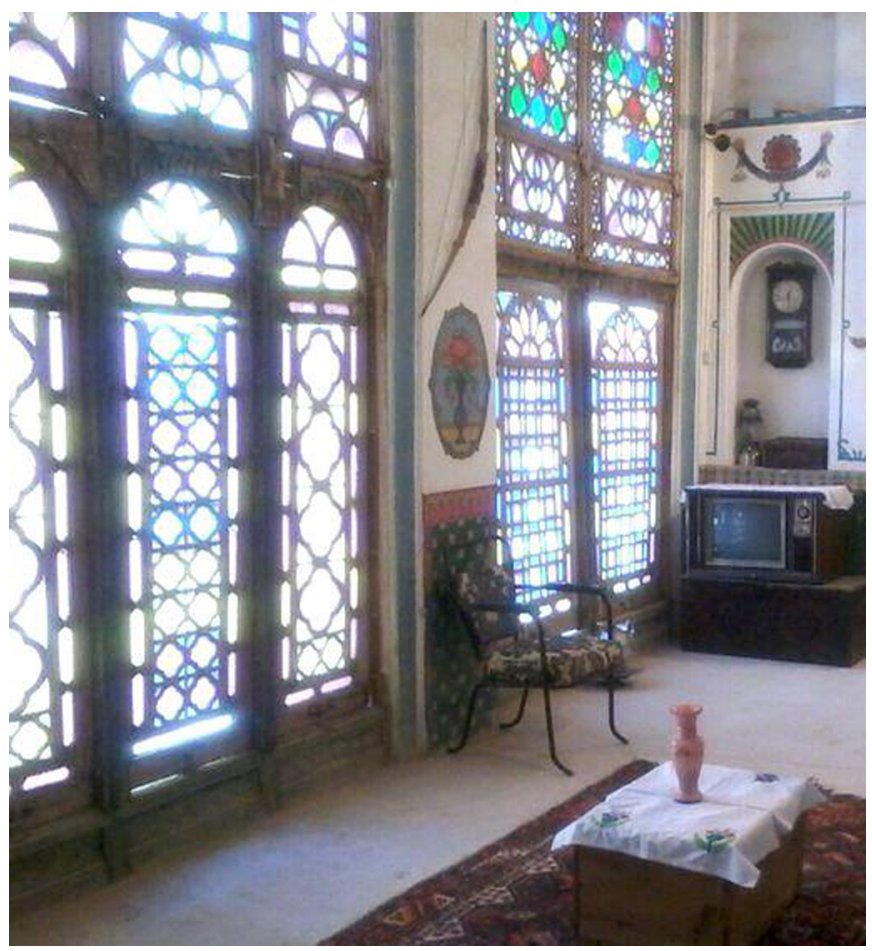

Fig. 4. Historic house of Sodagar in Evaz.

and cool air. Creating openings on the four sides of the tower assists the wind flow to enter more without difficulty. At this point, there are some simple and some with more beautiful works on it. A wind tower, which is located in Evaz, is shown on the top of the houses and four sided designs at the past where it was used in luxury houses (Fig. 2).

\subsection{Factors affecting architecture styles}

After the climatic conditions, political and security issues are the factors of creation of regions. When the country was unrest, Evaz as other cities of Iran became like a castle. The city was enclosed within a fence fortified with towers and

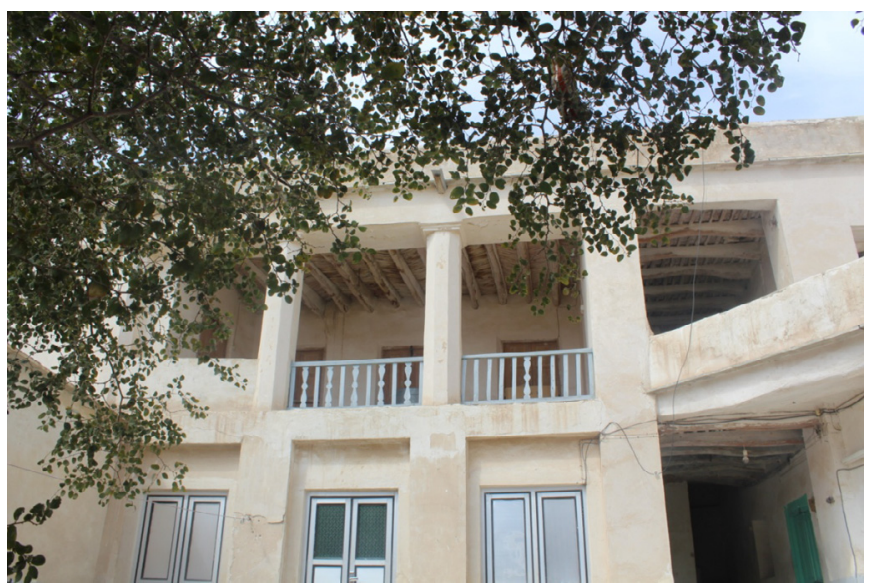

Fig. 5. More than 100 years old two storey residential building in Evaz, Esmaili Home.

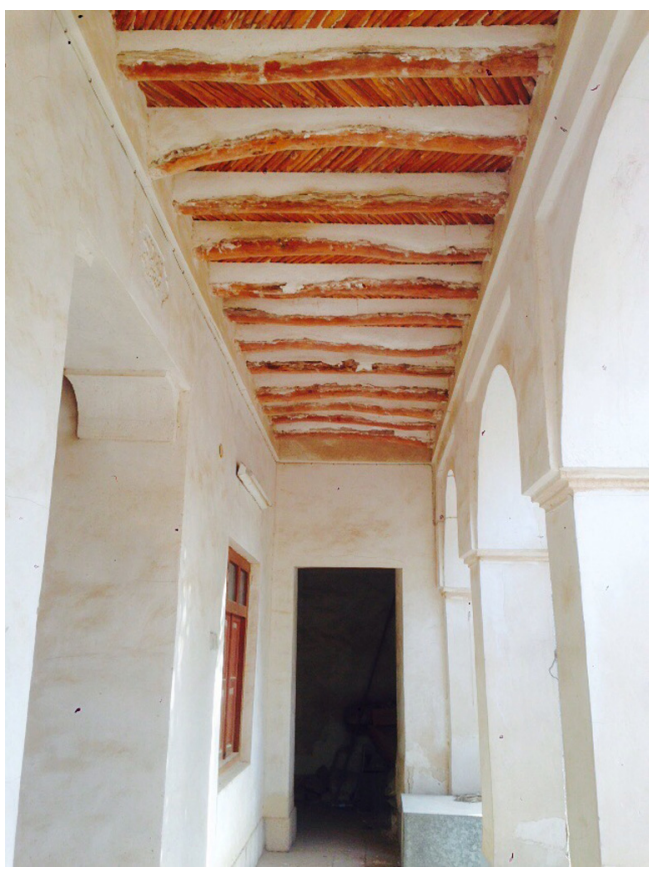

Fig. 6. Traditional ceiling design, Evaz, Mirahmadi house, July 2015 .

ramparts. To ensure the security of the city, the walls have been put up for several gates and guards for special defenses. Moreover, to further strengthen the two fences, surrounding ditch and water had been launched between the ditches [14].

Economic factors are another reason of formation of structures in architecture of ancient cities. In any society, political peace with the support of craftsmen and artists, i.e. talented people, will lead to economic growth. Creation of Gheisarie Bazar, shopping centers, caravanserais inside and out of the city and develops of pathways has straight impact on creation of contexture of the old city. Impact of religion is obvious in observing tombs and holy shrines, which was developed during that time. These tombs belong 
to outstanding spiritual personalities; in the old days, it was an attractive place for people to visit and observe religious ceremonies. Taste of board of governors and influential personalities is another impact on architecture and structure of old textures in each place [12].

Architecture of Evaz have inspired by many factors as mentioned earlier. During the history, some changes occurred that affected the city. Evazi people who are living in the Gulf region and who are interested in righteous support most of the peoples' needs.

\subsection{Overview of traditional architecture of houses}

Traditional architecture of hot and dry cities has been divided into two styles of introvert and eccentric. Evaz has introvert style. In this style, yard is located in the middle of the house and rooms are located around the courtyard, which is almost square shape (Fig. 3).

Due to the hot weather conditions and strong solar radiation, lighting design was carried out in a way to have shades and indirect natural light for interior spaces [15]. Most of the skylights were made from rock and plaster. In addition to add a beauty and brightness to the room, glass door was designed with colorful glass pieces to adjust the interior light (Fig. 4).

Ceiling of the ancient houses were flat and built with wooden beams. The beams were made from Tamarisk and palm tree, which are popular and grow well in the warm climates. In the middle of the ceiling, there was design of diamond, geometric shapes with paintings and colors, which made the design special and beautiful (Figs. 5 and $6)$.

One of the purposes in traditional home style was to make the home look animator and pleasant. That's the reason small garden is always a major key of the traditional architecture which was famous in Evaz. Variety of trees, which are suitable for the hot and dry climate was available in these gardens specially palm trees. Due to its high productivity and suitability of the dry climate of the region, palm tree was preferred by the people. Rock pools were used in some luxury house that assisted the view to look more attractive. For occupants' daily water needs, wells were drilled in houses (Fig. 7).

\subsection{History of water cistern (Berka) in Evaz}

Hot and dry climate conditions and the lack of adequate rainfall in more than six months in a year and seasonal rivers were the reason to motivate architecture to create new ideas of the cisterns, bands and canals. Cisterns were made to save water in rainy days. Water cisterns are important not only as one of the most important structures of water cisterns, but also was guidance for passengers and caravans in the past for whom were passing the way in the desert and plain (Fig. 8).

Accordingly, the cisterns are a symbol of architecture of rural in Iran. The oldest water resource in Iran belongs to Eilami Dorantash in Chaghazanbil of Khuzestan state (province). This water cistern is build 1250 years ago. There are many water cisterns located in the south of Iran and islands in Persian Gulf, which have proven the value and importance of human to secure a vital element, water [12]. In Islamic era, water cisterns had increased rapidly and today there are many historic places from those periods. Water cisterns usually are divided in two categories; the water cisterns which are used generally by everyone in the area and region (more public), and the second ones that are more private water cistern for inside the houses.

\section{Criteria of Evaz cisterns}

Evaz cisterns are one of the most famous cisterns in the region. Generally, the original plan of the cistern is available in two designs.

- circular plan and domes roof (Fig. 9);

- rectangle plan.

The design of water resources are the common ones in the southern of Iran. The resource of the water in these cisterns comes in the cylinder shape, which has been constructed in the middle of the ground. Ratio of diameter in the source depends on the size of the pond. Domes were used for circular pond designs and were calculated acquiring mathematical calculations with the most suitable materials that helped them last for long time and stay aesthetically beautiful.

\subsection{Construction method of the water cistern}

People in the past were using traditional ways to build this vital element; there were different ways of constructing these famous cisterns. The device, which they were using, called Pargar (compass); this was used to create the dome shape. Pargar made from a board where four sides of that board were ropes, which were connected to four sides of the pond. Therefore, the architecture of the pond became round shape with the ropes until it reached the required size of the dome, and this was the way to create an accurate environment of the pond.

On the top of the pond, there is a stone element called 'Kakol' when it appears, it means that the work is completed. The dome was installed on the wall, which is called 'Ghors' meaning strong and fit base. In addition, it gave height to the cistern. The base (Ghors) helps cisterns' height to be higher and at the same time helps to the movement of airflow, which effects the water to be fresh and cold [12].

\subsection{Shape of the dome}

To make the shape of the dome, the architecture was constructed from stones, row by row, and each new row was organized by the stones more forward. Usually after building four rows, ceiling should get one-meter slope to achieve the shape of the dome. In the huge sizes of cisterns, two Ghors (bases) were required to put the dome on it (Fig. 10). After building the dome, outline was covered by mortar, to protect the mortar from the cracks, resulted by water and strong heat waves in this area, also covered by plaster and clay. 


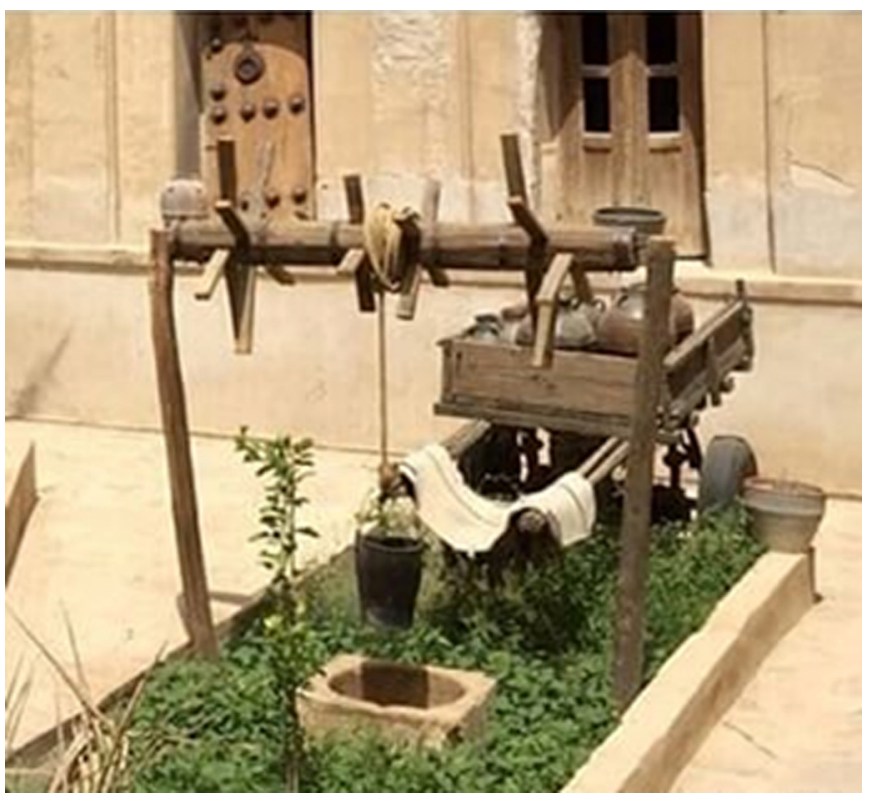

Fig. 7. Wells in houses for daily water use in Evaz museum.

To minimize solar radiation and heat transfer, they had made the cover of the cistern with plaster. In addition, the white color of the plaster helps travelers to be aware of water cistern from distance.

\subsection{Air conditioning in the cisterns}

In Evaz's cisterns, the holes are used around the cistern with the specific distances instead of the wind tower (Fig. 11) [16].

\subsection{Materials used in the water cistern}

Certain materials used in the construction of the pond. Stone and mortar are used in the floor (source) of the ponds and in building stone tablets. The mortar is made soft, hardly with shovel. Unlike plaster, mortar can be very resistant and durable in an environment where there is a lack of water. The plaster is dry and away from water can be more durable based on the experiences and human resources over time, Homeira Kamal has mentioned in his book [12]. Accordingly, mortar used for floors and walls, which is directly connected to the water and plaster used for domes and the top that is in dry area and under the sun.

Nowadays, because of the difficulties in making mortar material, architecture is using cement instead of mortar, which does not have the same value of mortar. In addition to the design of the cistern in the past, two shelters with stone platform were built attached to the cistern for passengers and caravans whom were passing that way, but nowadays, this is no longer used anymore. The way to the access a water source was through stone stairs, which were made inside the cistern periodically. The amount of the stairs depended on the size of the cistern. In the front of the cistern, in the direction of water flow were small, hence this part of the pond protects water from waste and other suspended items.

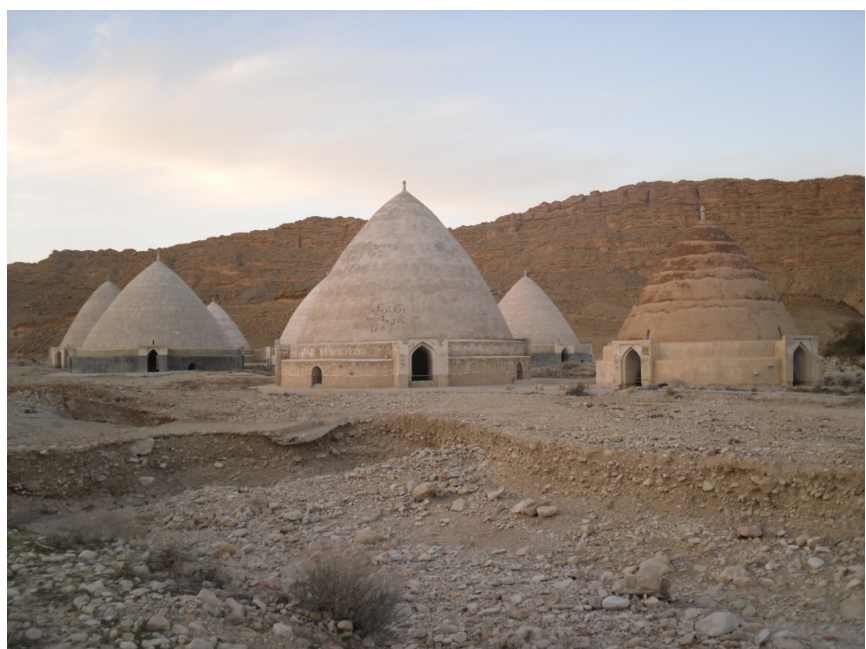

Fig. 8. Evaz cisterns, July 2011.

This specification was applied in cisterns out of the city as well with a small difference. In cisterns out of the city, there were platform in the direction of Qebla (Muslims' pray direction) for passengers who wanted to pray in the comfortable place. Mostly the cisterns belonged to Safavie Empire (1502-1736), which was repaired after. Below are some examples of water cisterns in Evaz:

\subsection{Mulla Mohamad water cistern}

Mulla Mohamad water cistern was built more than 750 years ago in Afshari period and is one of the most famous water cisterns in Larestan region, and despite the long years of standing, still remains strong [17]. This infrastructure is made in round and dome shape. The great dome stands on two bases (Ghors) where one base is higher than the other as it was much easier for architects to build it that way. The water cisterns have been repaired and reconstructed several times during their life span. When it rained, the water came from a faraway to the water cistern by a channel or river, which is also known as river from the top (Roode Bala). Water entered Mulla Muhammad cistern and once it was full, it then moved to the next water cistern. After the Mulla Mohammad water cistern, the water entered the Haj Ghanber water cistern, which is also located beside it. Nowadays also, people are used to getting water for their daily use from the Mulla Mohammad water cistern as before like in the past [12] (Fig. 12).

\subsection{Water cisterns in Nakhlestan Bereneh (Bereneh Groves)}

In the set of Bereneh Groves, there are four water cisterns with two different shapes of circular and rectangle plans. The water cisterns had been made in different sizes with materials, such as stones, mortar and plaster. The set is divided into two shapes; circular and rectangle. The circular plan water cistern was named as the two fold Solfa 1 and Solfa 2 , and Rafeyei water cistern. The Solfa water cistern is made in circular and dome shapes and the top of the dome, there is a 


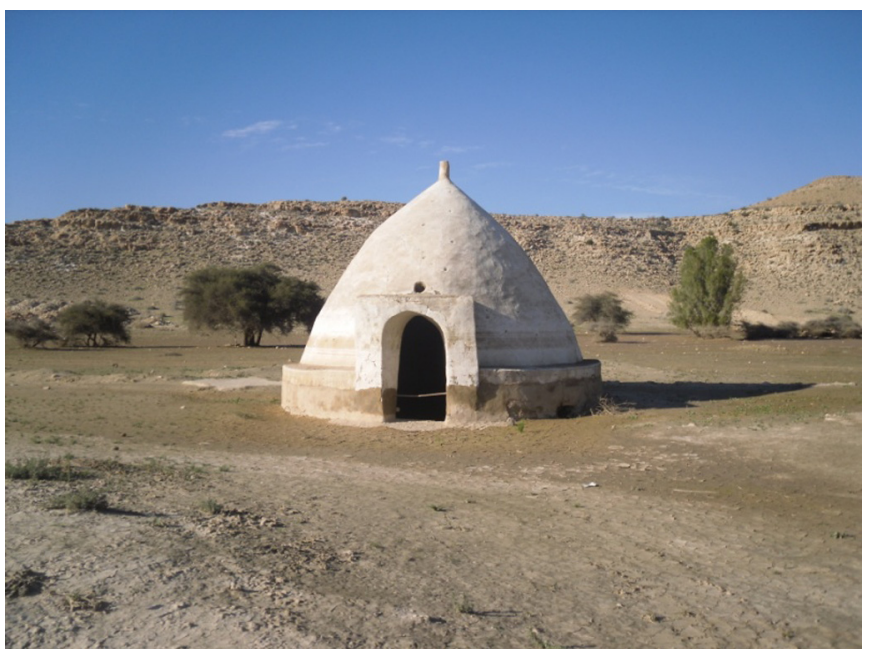

Fig. 9. Circular plan and domes roof, July 2011.

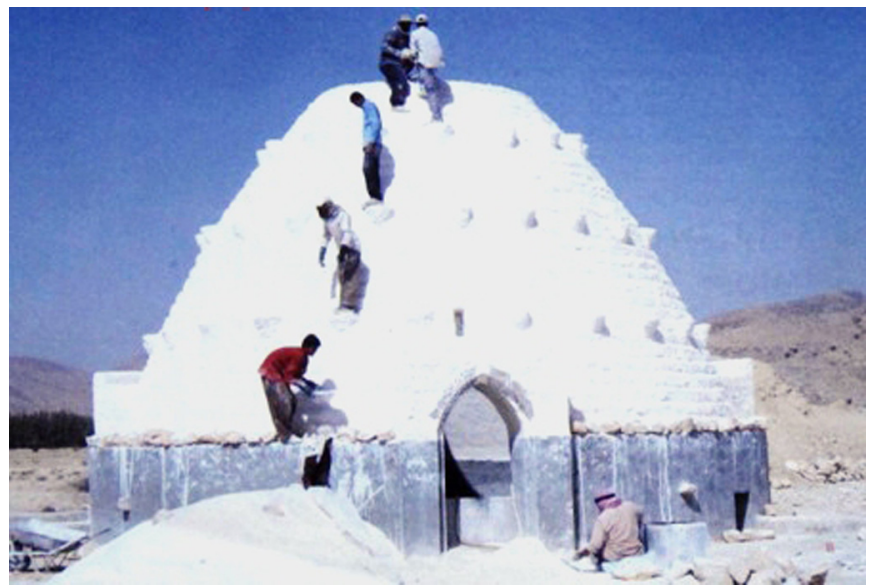

Fig. 10. Circular plan and domes roof, July 2011.

small part, which is similar to identical small column. The water cisterns are in middle size and originally had three entrances for collecting water, although today, two of the entrances are closed and only one is open for use. The materials used in this water cistern are stone, mortar and plaster (Fig. 13).

Nowadays, the water of this cistern is not useable but the structure is still strong and has good condition. On the southern arch of the cistern, on an old stone, there is a print that this water cistern is known as Solfa water cistern and was built by Haji Mahmoud Shamsayan at 891 Hijri Gahamri, and repaired by Mohammad Amin Rafeyi, son of Abdulla, at 1391 Hijri Ghamari for public use. Moreover, Solfa cistern is registered in the list of Monuments of Fars. Rafeyi water cistern is another type of circular water cistern of the Nakhlestan Bereneh, which has a large size and a circular plan with conical shaped dome ceiling, and the small part on the top is called stone tassel (Kakole Sangi). The exterior of the water cistern is covered by mortar then thatch and plaster to extend the durability [12].

Today, four arch shaped entrances help to transfer the water inside. Only one rectangular shape of water cistern is available in the set of Nakhlestan Bereneh. This structure has

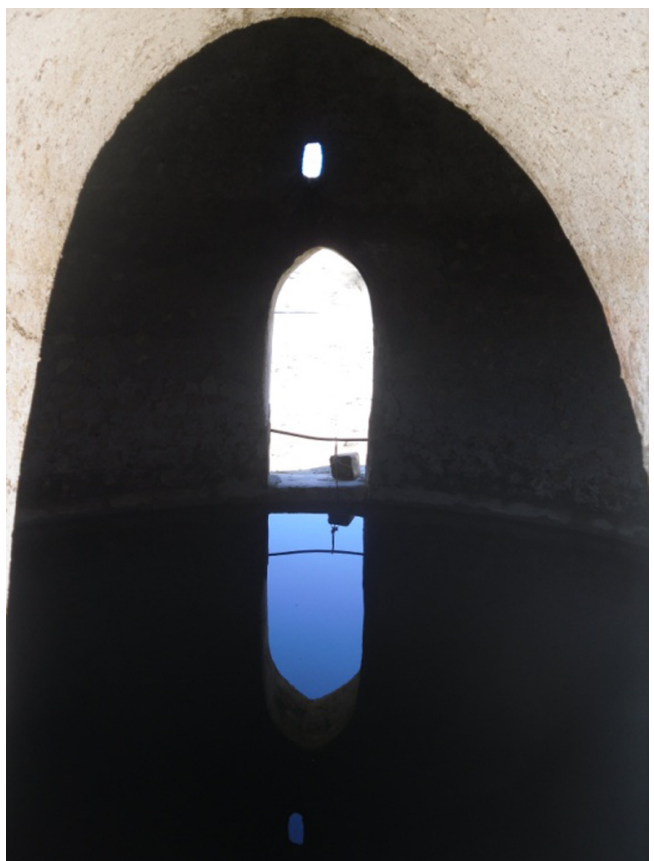

Fig. 11. Holes around the water cistern, July 2011.

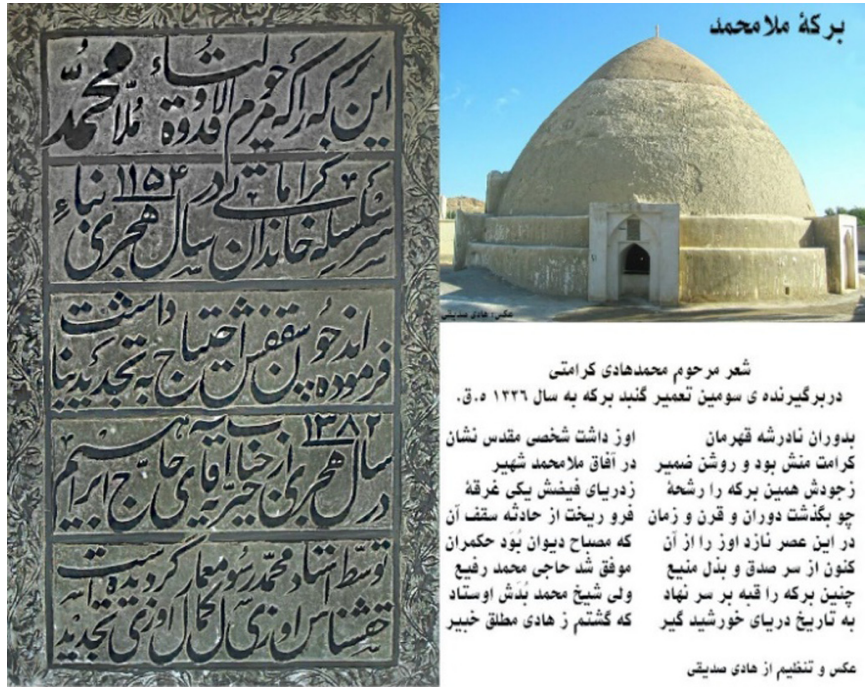

Fig. 12. Mulla Mohammad water cistern and the inscription, July 2011 [17].

a large size and has two entrances on the eastern and western sides, and there is no print of any information on the structure. This water cistern today does not have good condition and has some cracks, which should be repaired as soon as possible otherwise this beautiful structure may be destroyed (Fig. 14).

\subsection{The water cisterns square (Meidane Larde Berka)}

Originally had nine water cisterns in the famous square of "Larde Berkah" but recently two of them has been totally destroyed. The builders name are unknown unfortunately 


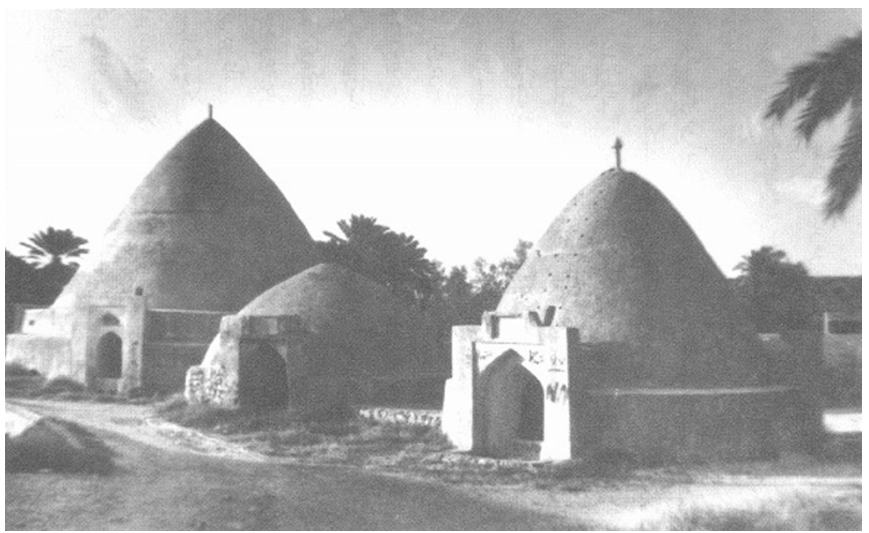

Fig. 13. Nakhlestan Bereneh, June 2004.

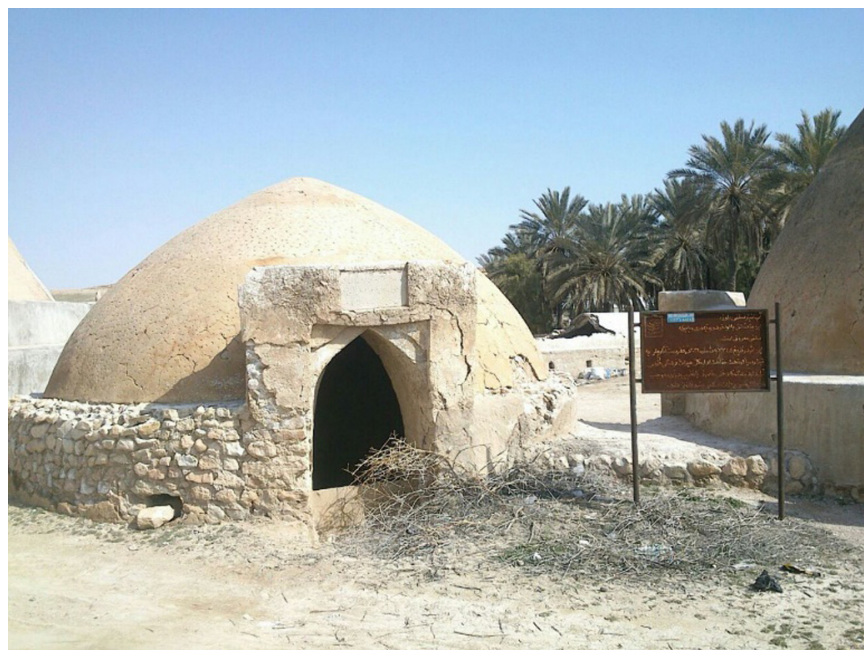

Fig. 14. Solfa water cistern and the inscription, June 2012.

but from the design and the shape of the water cistern, which is circular and has a dome ceiling with the material of stone used, plaster and mortar, archeologists has been noted the historical value of the water cisterns in this area. In this set of the water cisterns, there are some water cisterns, which are more well-known than the others, such as Agha water cistern (builder is Agha Abdul Lari), Haji Mohammad Zaman (name of the person responsible for this water cistern but was built by Mir Mohammad Taghi), Sar'ab, Dokorsi (built by Abdulrahim Aziz Hghshenas), Lagi, Sheikha (built by Sheikh), Dotey Takhi. Those with no names mentioned are without any writing or print on the water cisterns [12] (Figs. 15 and 16).

\subsection{Sheikh's water cistern}

The structure of sheikh water cistern is medium size and it has a round shape with dome ceiling and the tassel stone on the top of it. This water cistern is from the type of cistern, which has a short dome. The exterior of the dome is covered in order by mortar and after by thatch. In general, the materials of this structure are mortar, plaster and stone. The water cistern has four entrances with vault and the concept is to be symmetric. From each of the entrance, there is a place for

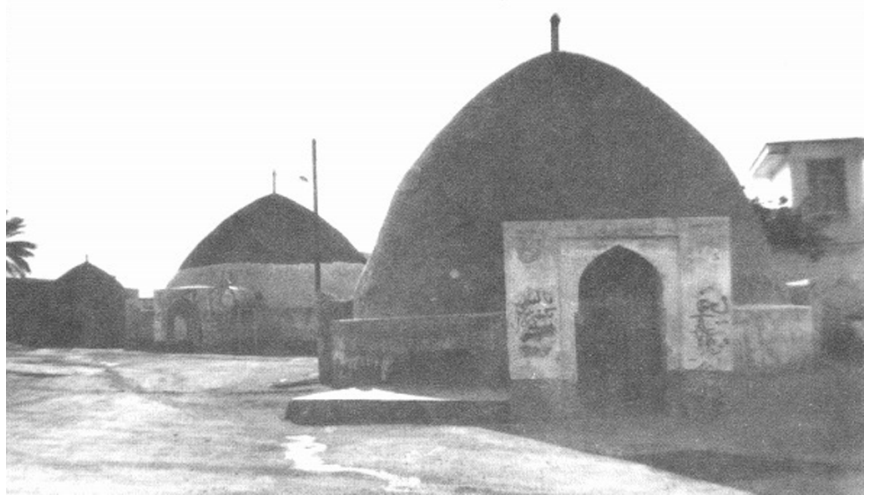

Fig. 15. The water cisterns square (Meidane Larde Berka), June 2004 .

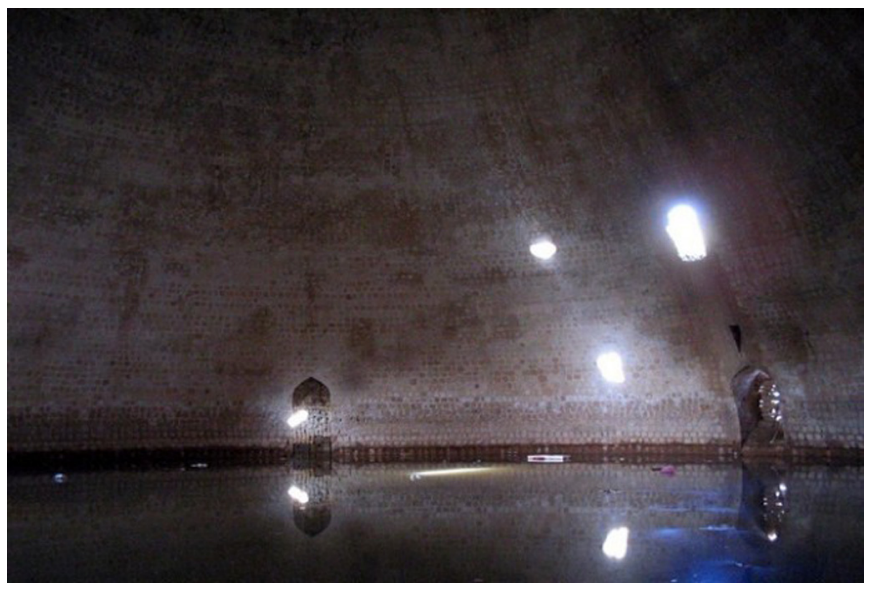

Fig. 16. Holes around the water cistern [16].

water to enter and to be collected inside the cistern. On the east vault entrance, there was a stone frame where eight verses of poem are written on it. Unfortunately, these poetries are not readable now. At the end of the poem, it shows the date of 1335 Hijri Ghamari. The builder of this water cistern is Mohammad Sharif Faghihi. The structure of Sheikh water cistern is still good and it is close to Musalla mosque, which is one of the well-known mosques in Evaz.

\subsection{Reis Mohammad Saeed Sodagar water cistern}

This water cistern is located in Moallem Street, close to the Musalla mosque, same as Sheikh's water cistern. In general, the materials used are mortar, plaster and stone. The structure of the water cistern is large and in round shape with dome ceiling as well. This cistern has two disks (Ghors); the first disk is higher than the second one. On the top, there is a tassel stone appearing. The structure of this water cistern has six entrances for the water, however nowadays, only four of them are in use and the other two have been blocked. Local architecture designed the water cisterns as per the peoples' need according to Evaz's climate conditions, which is mostly hot and dry, and therefore the shaded part is designed as well for people to stand there and collect the water from the cistern. 
How much is important Ewaz water cisterns for the people of that region?

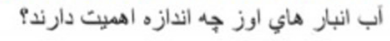
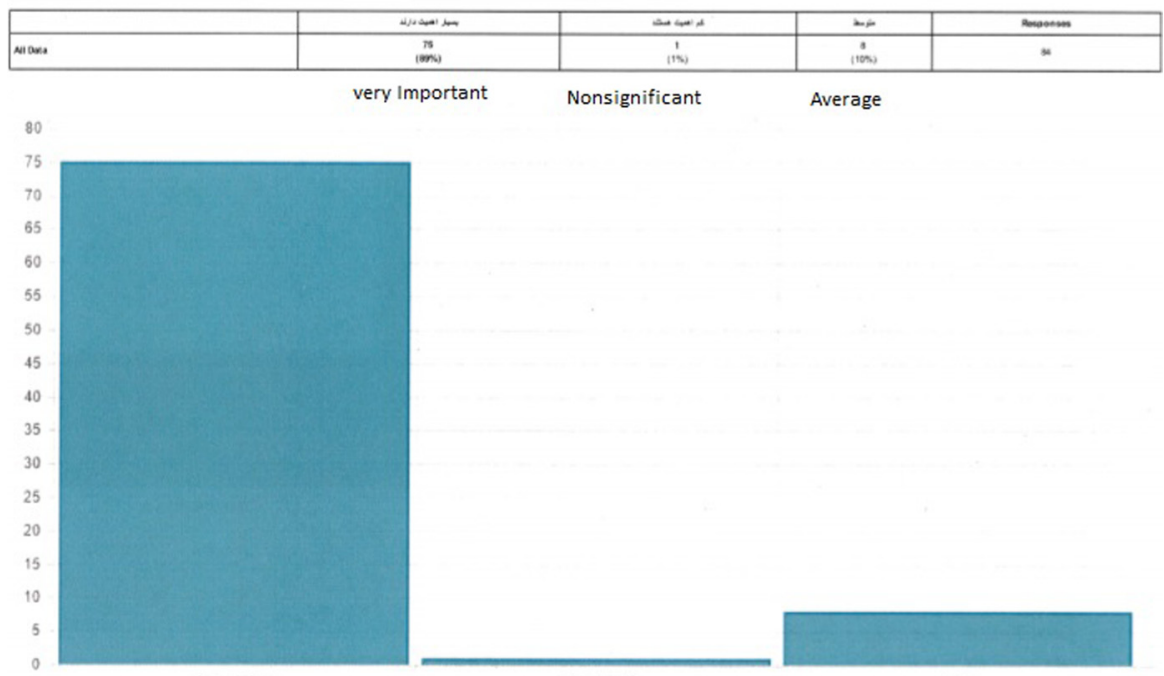

very Important

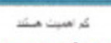

Nonsignificant

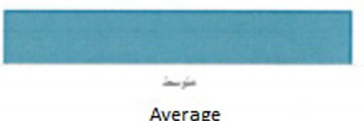

Fig. 17. People's opinion about the importance of water cistern.

How many percentage of the drinking water in Ewaz is provided from water cistern?

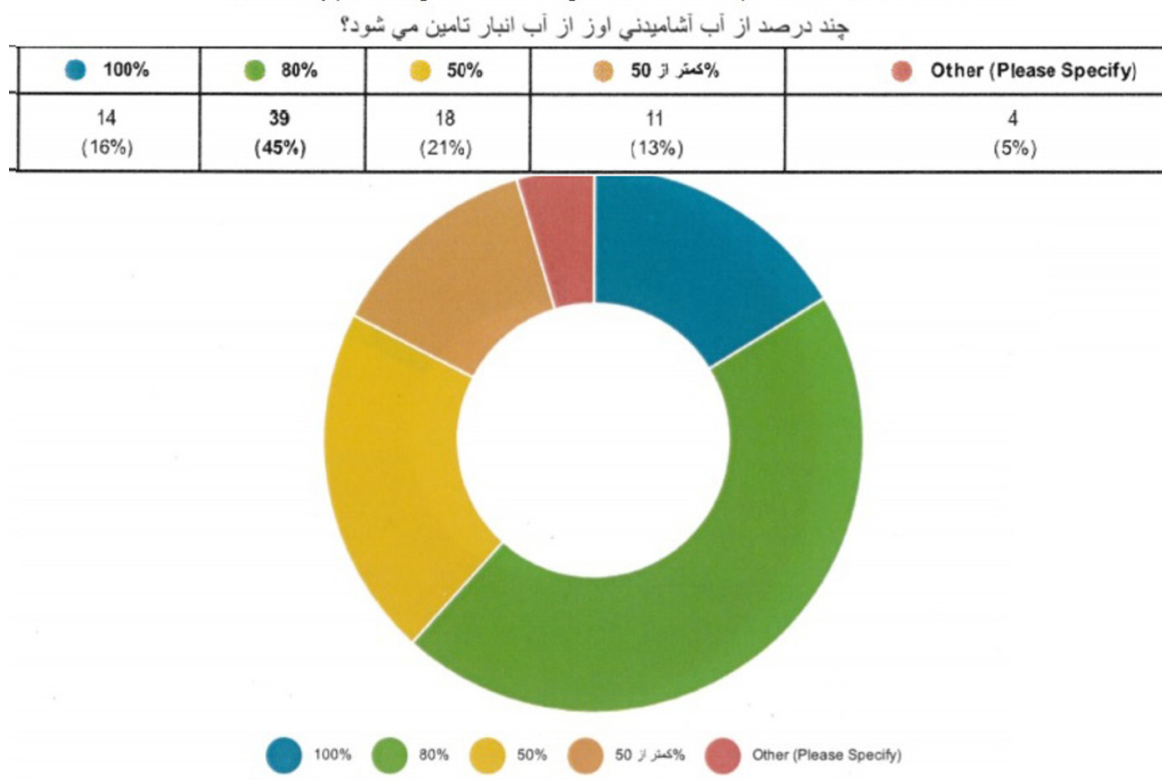

Text Responses

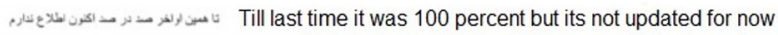

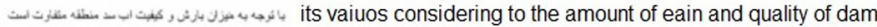

right now it can be around $70 \%$
\end{abstract}

Fig. 18. Demand for water use from water cisterns.

\section{Current water and climate situation in \\ Evaz}

Lack of water and hot climate has created the reason for native people to immigrate $[15,18]$. Since long time back Evaz faced with an issue of drinking water. In the past, the city's tap water was salty, it was only for use of washing, and watering the plants, however in January 2008, they started to use fresh water piping network of the city of Salman Farsi Dam. Although Evaz is still facing the same issue of water shortage and the use of water from cisterns to supply its water demand, it has become an issue for the city because of the abundance of fresh water that is subject to sufficient rainfall to fill the Salman Farsi Dam [19]. In the 


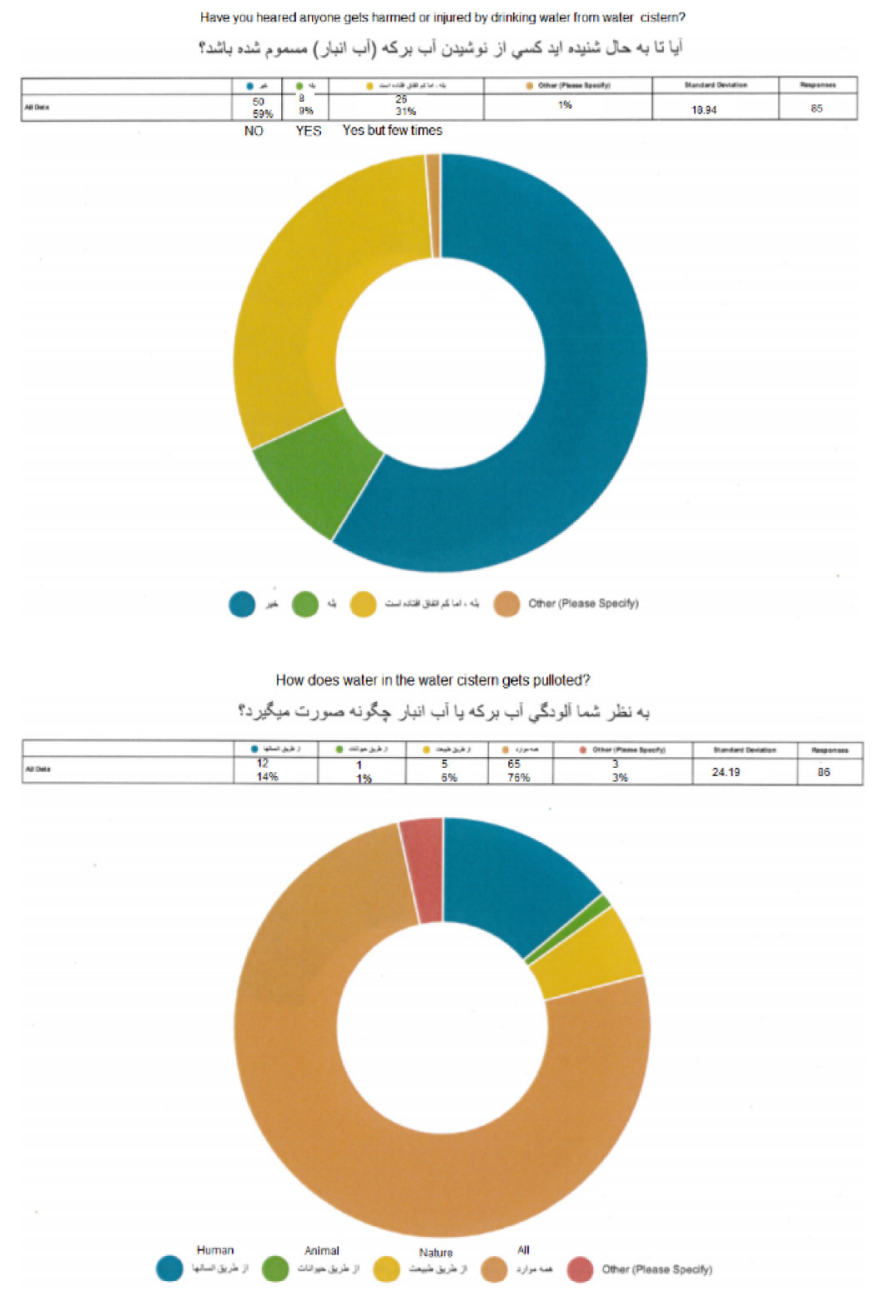

Fig. 19. Likely pollutions caused by water cisterns.

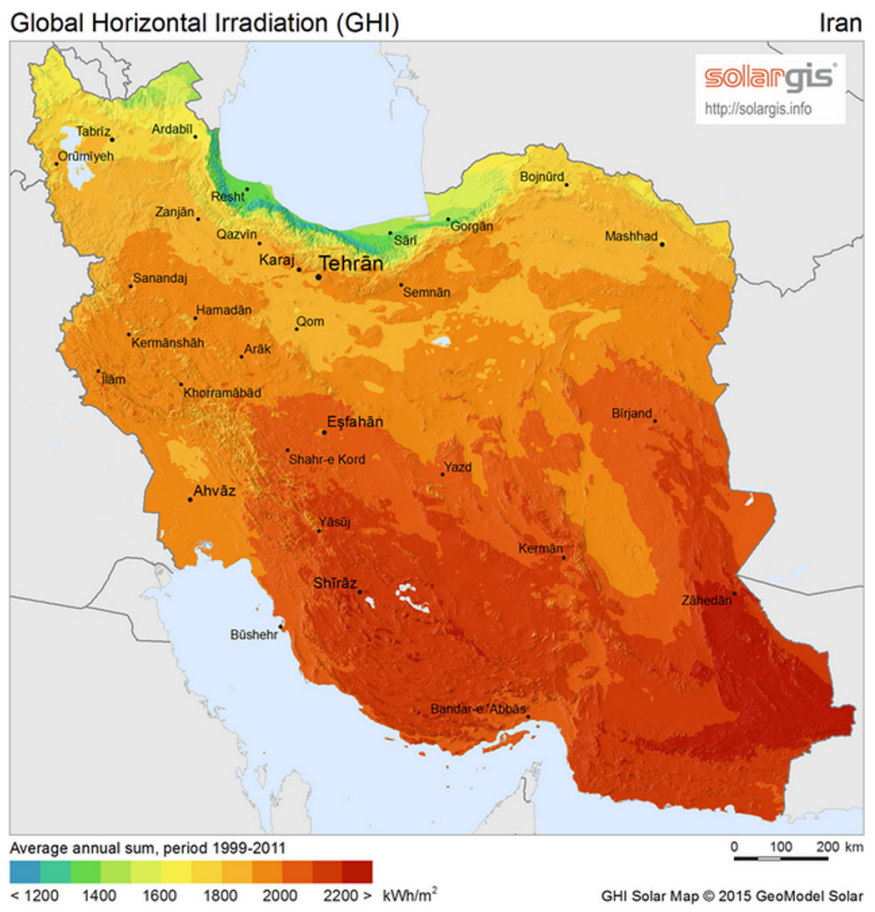

Fig. 20. Radiation of sun in Iran (1999-2011) [43].

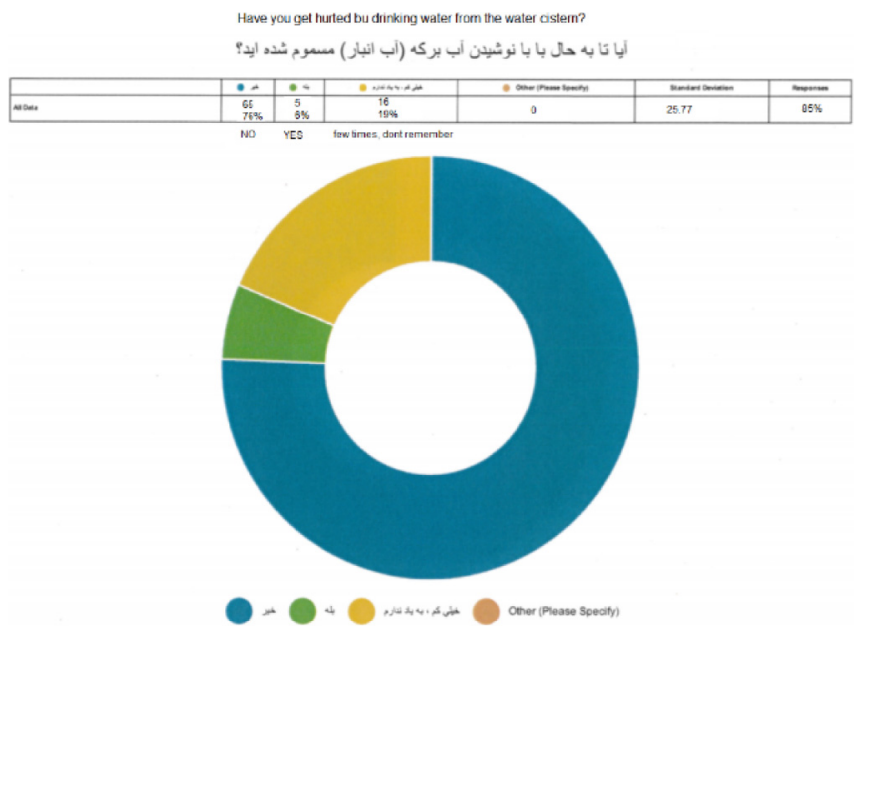

past as well as today, the main source of drinking water came from the large stocks of the cisterns inside and outside the city. According to the latest statistics, about 750 large and small scale cisterns (water reservoirs) were made by the people of the region to supply drinking water in the city [6].

\section{Importance of the water cisterns}

Water cisterns are one of the most important elements in Evaz city. People are still consuming the water from these settings. According to the survey conducted, which was created for the purpose of the value of the water cisterns and were distributed among Evazi people, the results have shown high levels of importance of the water cisterns for people in this region (Fig. 17). The graphs show the amount of value of the water cistern aimed at the citizenry of the Evaz and the region. According to the first graph (Fig. 17), $89 \%$ of the citizenry believe that water cistern is very important for peoples' life in Evaz. While exclusively $1 \%$ believe, it is not so significant for the region. The rest $10 \%$ indicated that the water cisterns are important element of the region. In summary, most of the people $(99 \%)$ believe that water cisterns are important for continuity of peoples' life. 


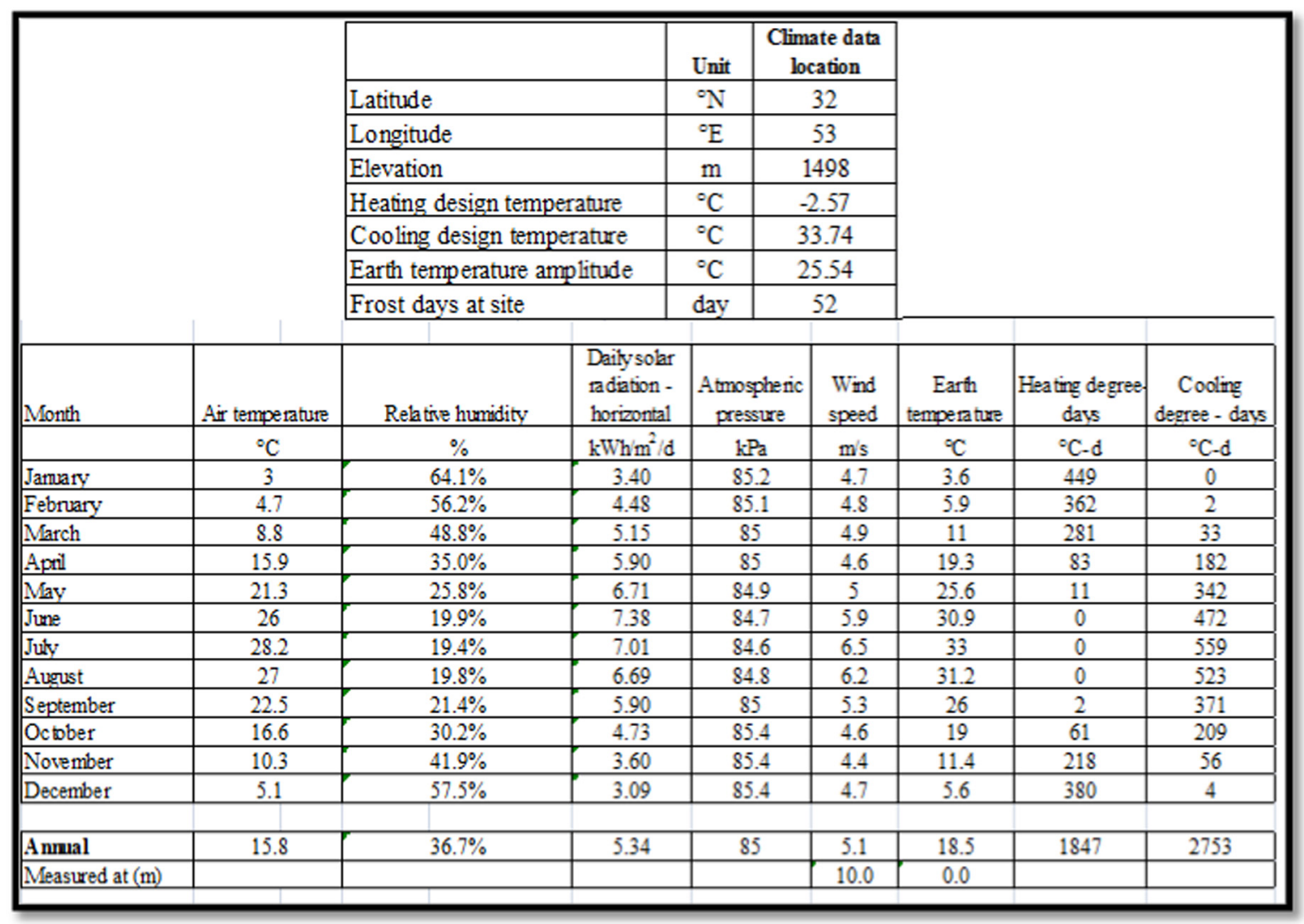

Fig. 21. Specification of the climate data in different months of the year [20].

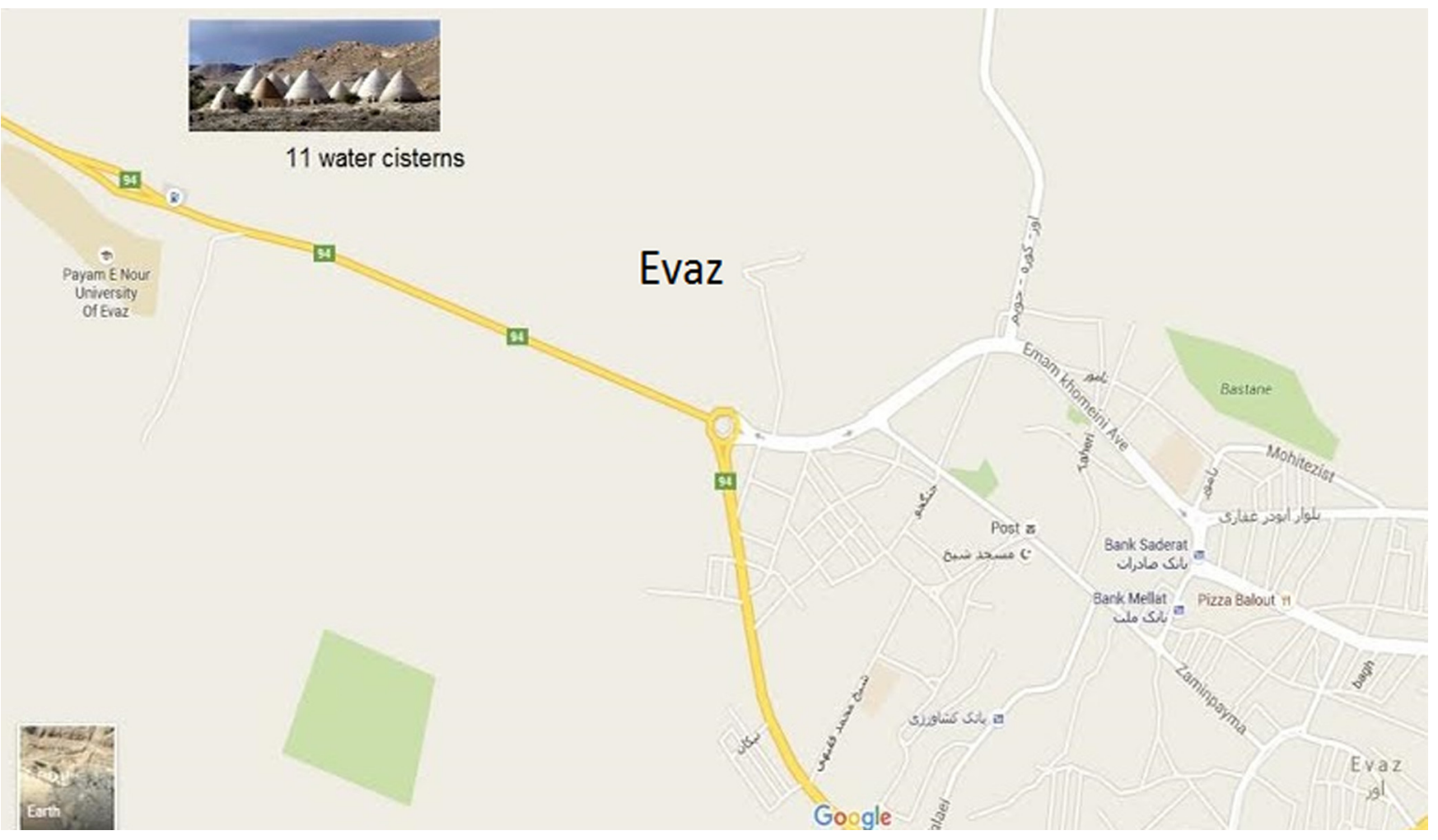

Fig. 22. Site plan of the 11-water cistern (Google map, 2016). 

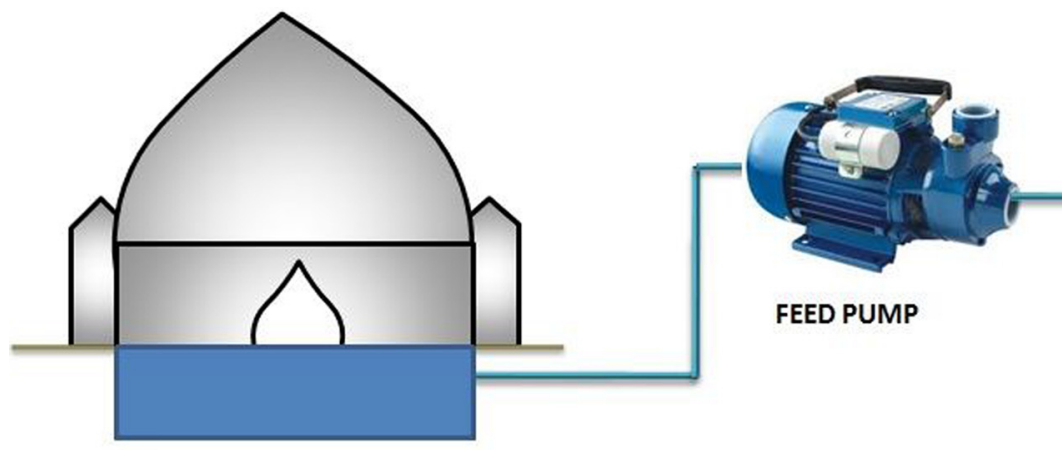

FEED PUMP
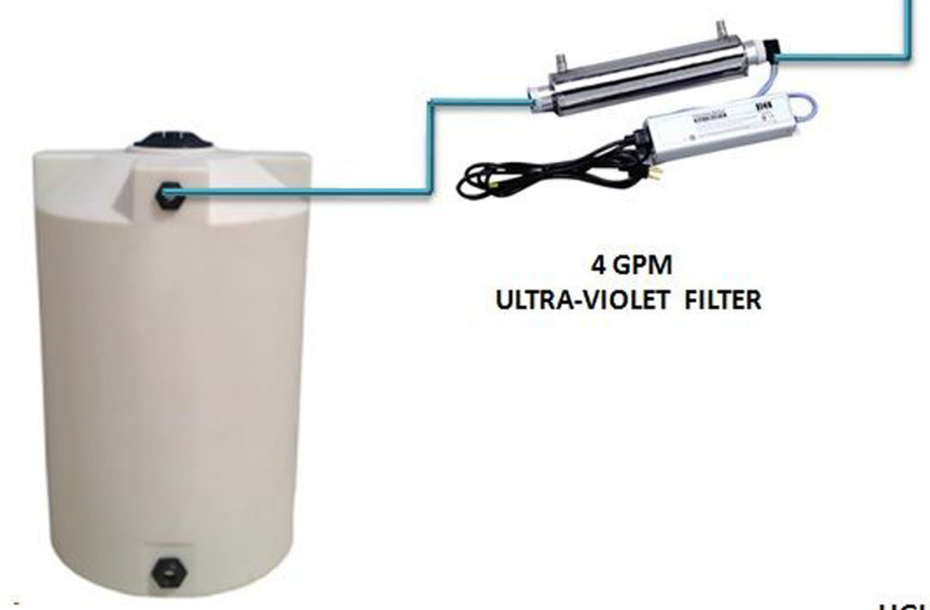

4 GPM

ULTRA-VIOLET FILTER

Fig. 23. Detail of water filtration process [27].

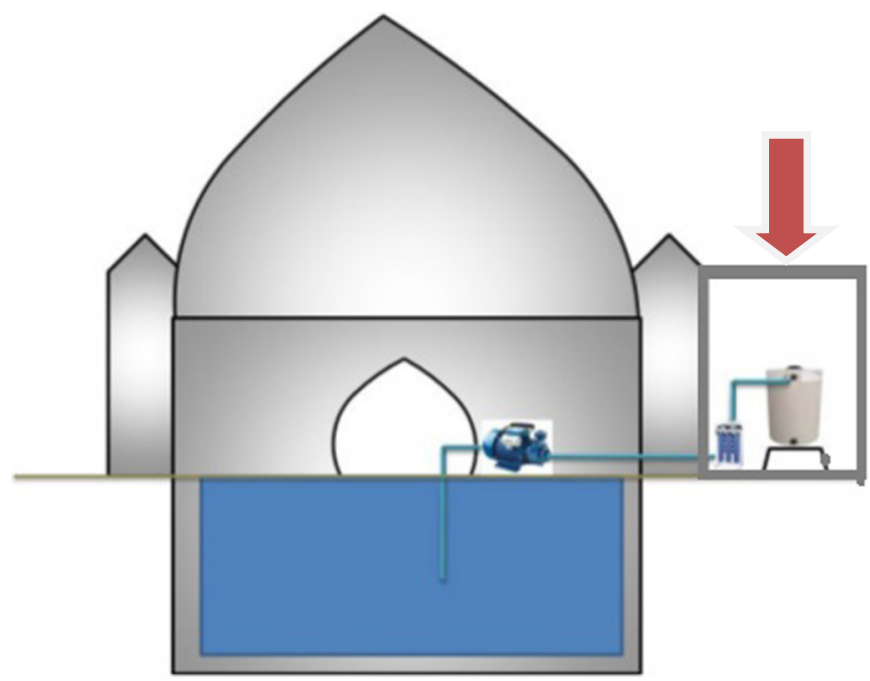

Fig. 24. Detail of water filtration process [27].

According to the second graph (Fig. 18), $14 \%$ of the Evaz citizens believe $100 \%$ of drinking water in Evaz is provided by water cisterns although $11 \%$ believe the use of water from water cisterns is less than $50 \%$. On the other hand, $39 \%$ of Evaz citizens replied to the question that the amount of water consuming from the water cisterns are $80 \%$. As a result, $18 \%$ believe that $50 \%$ of water supplies are from the ancient structures. Hence, $11 \%$ of Evaz citizens had voted for less than $50 \%$ of water consumed through the same source and therefore the others had voted for more than $50 \%$. This is the main reason for immediate search for longer term solutions for sustainability of the water cisterns in this region. The other resource of water is Salman Dam, which is not in full capacity and limited with water all year round, and in such cases, water cisterns play a big role to satisfy the need of the residents. Thus, improving and updating the system of the water cistern is essential for the life of the citizens.

\section{Challenges with water cisterns}

The biggest challenge, as mentioned earlier, is the lack of rainfall, which is related with the climate conditions. Moreover, there are some other issues occurred in the recent years and has become the main cause to stop using some of the water cisterns. The quality of water, particularly after droughts, reduced because for long time water is unmoved and some people do not want to use water through healthy ways, and thus the place could have contamination. As a result, people stopped using them. On the other hand, the study proposes some 


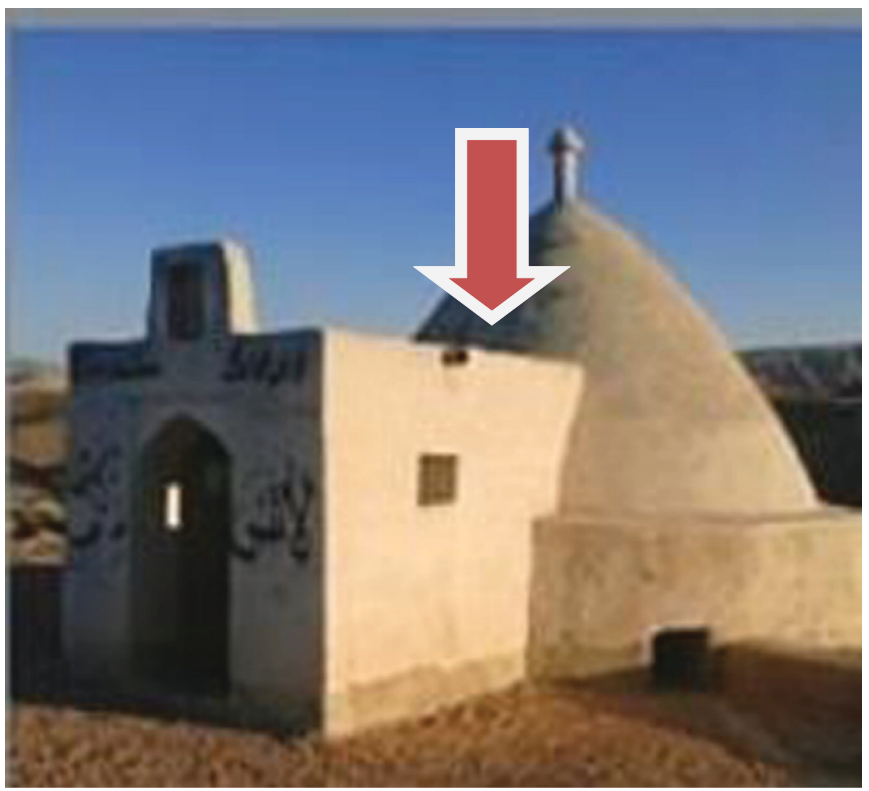

Fig. 25. Space where water filtration and tank devices will be located.

sustainable solutions for helping the current issues with new enchased designs to help continue with the use of rainwater in a face of fresh and healthy way $[20,21]$. As soon as most of the water requirements are supported by cisterns, it is necessary to solve human health hazards in water cisterns. The main factors, which could cause issues for water cisterns, are as follows:

- water pollution;

- destruction inside the water cistern;

- pollution caused by people;

- pollution caused by animals;

- damages by nature.

While Evazi people are using water cisterns as part of their day-to-day life, a survey has been created to share the information regarding pollutions that may be caused by water cisterns (Fig. 19).

\subsection{Potential sustainable solutions}

The best way to protect the water from microbe and bacteria is through water filtration. Water filter machine can create movement in the water in addition to kill the bacteria and hazards within. To activate the filter electricity is the major element, which is required but the lack of power potential, is another issue that also requires another solution. As mentioned before, Evaz has a strong solar power, which has not been used until today. Using solar panel to produce electricity for those water cisterns will be a good idea. As per the study on different kind of solar panels, it has been discovered that with installation of a solar panel on one cistern can produce electricity power to nine other cisterns as well [22-24]. Solar radiation in the south orientation is more powerful than any other orientation (Figs. 20 and 21).
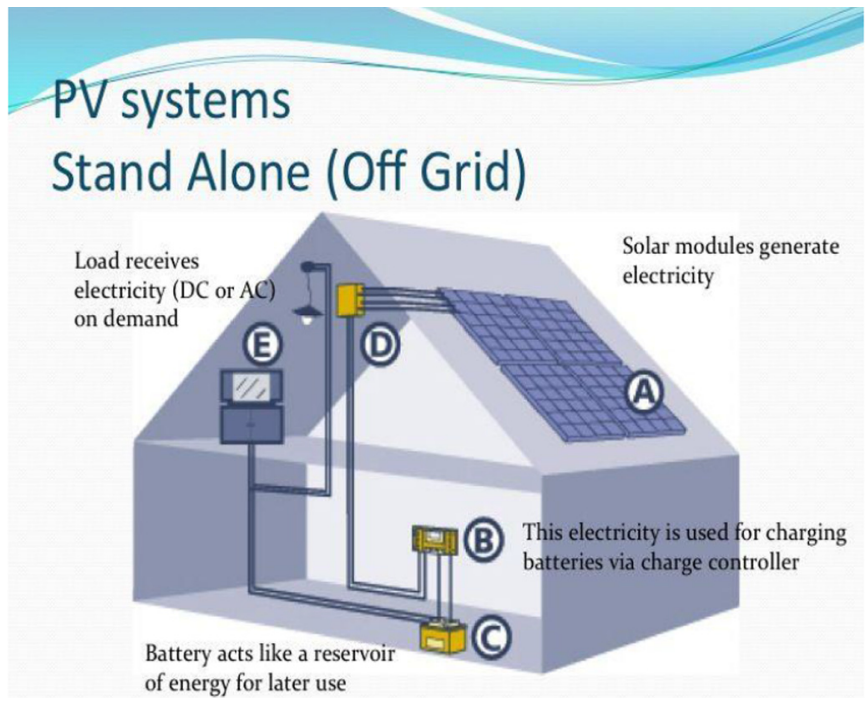

Fig. 26. Process of the solar panel [32].

\section{Site plan}

The site that has been selected contains the eleven water cisterns, which is in front of the Payam Noor University in Evaz city. This place is not too far for people to come and collect water. In order to test the feasibility of the proposed solutions on water cisterns, the site of Payam Noor is selected (Fig. 22).

\section{Feasibility study 10.1 Water filtration device}

An investigation has been carried out on the required water filtration device and its process to analyze what kind of the pump and capacity is suitable for water cisterns. After discussing with professionals and engineers, the following solution was determined, which was provided from the similar projects in literature review although the differences have been noted and the requirements of the Evaz water cisterns have been enhanced with water harvesting systems from different countries [25-27].

The $1 / 2$ feed pump will be handling the suction of the water and will produce the necessary pressure in feeding the Reverse Osmosis (RO) system with water coming from the cistern. Then, in the 400 GPD (Gallons per day) light commercial RO water filtration system, there are five RO stages.

First stage is Sediment Pre-filter; screens out dirt, sand, rust and other microscopic particles 15 times smaller than a grain of sand.

Second stage is Carbon Pre-filter; granular activated carbon to reduce chlorine, colour, odour while absorbing volatile.

Third stage is Carbon Pre-filter; activated carbon block pre-filter reduces elements that cause water to taste and smell unpleasant, including the taste and odour of chlorine.

Next stage is RO membrane. Here, TFC RO Membrane with pores of 0.0001 micron squeezes out the dissolved substances, including radium, virus, bacteria, salt lead, heavy metals, arsenic and many others. 


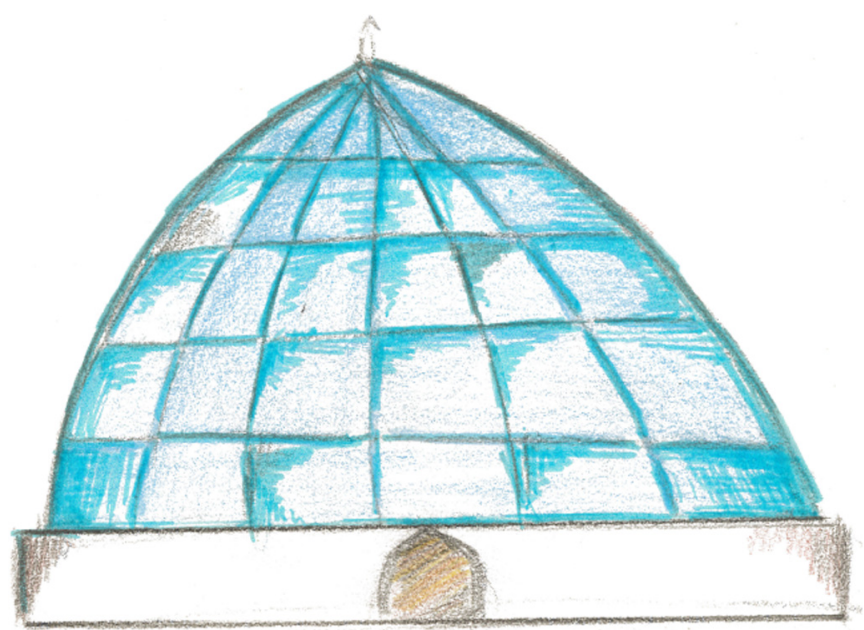

Fig. 27. Dome shape solar panel, proof of concept.

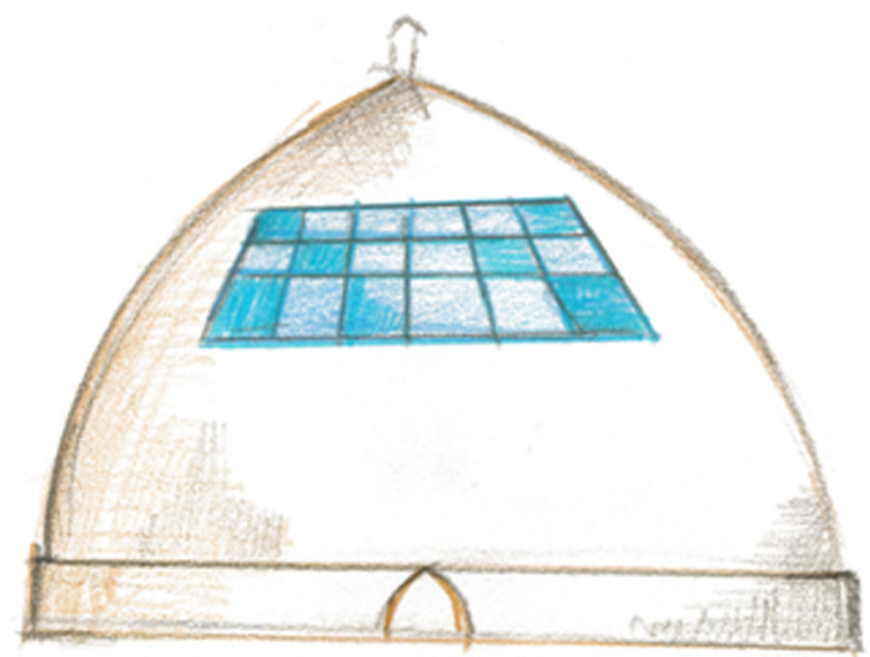

Fig. 28. Rectangle shape solar panel, proof of concept.

The last stage is the post filter. Post polishing carbon filter removes any possible residual taste from the tank. The recommended replacement time is replacing the Sediment Pre-filter and Carbon Pre-filter at least 4-6 months and the recommended replacement of the RO membrane and Post Filter is once every $2-3$ years.

Next, is the 4 GMP (Gallons per minute) Ultraviolet (UV) filter. UV water purification is the most effective method for disinfecting bacteria from the water. UV rays penetrate harmful pathogens in water and destroy illnesscausing microorganisms by attacking their genetic core DNA (Deoxyribonucleic Acid). In the final stage, 100 Gallons food grade storage tank will be placed onsite that can accommodate the water consumption of the residents (Figs. 23-25) [27].

- 4 GPM UV: $24 \mathrm{~W}, 220 / 240 \mathrm{~V}$ AC, $50 / 60 \mathrm{~Hz}$ (per day consumption: (0.576 kW h/day);

- RO SYSTEM: $1.2 \times 4=4.8 \mathrm{~A}, 220 / 240 \mathrm{~V} \mathrm{AC,} 50 / 60 \mathrm{~Hz}$ (per day consumption: $(2.76 \mathrm{kWh} /$ day);

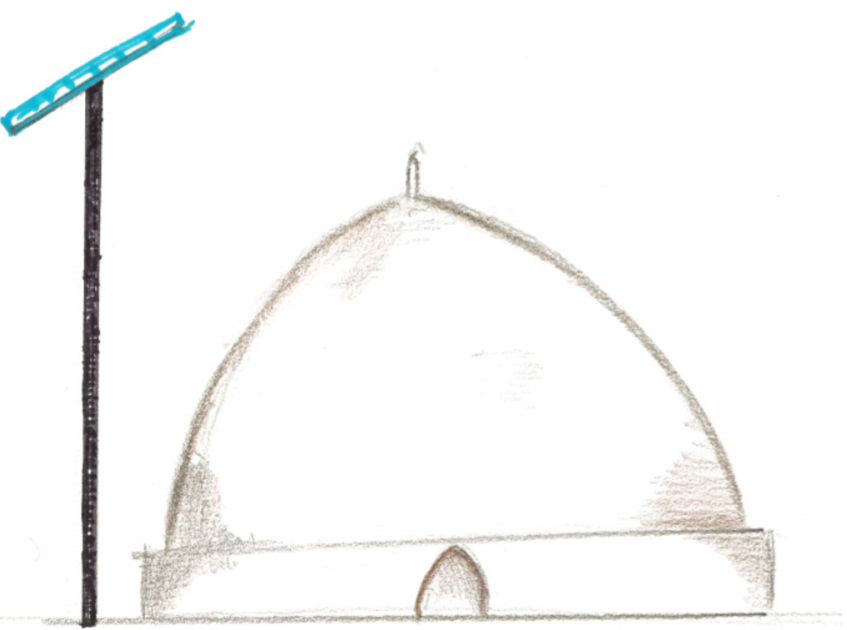

Fig. 29. Water cistern and the solar panel on the side, proof of concept.

- PUMP: 1/2 HP, 0.37 kW, 220/240 V AC, 50/60 Hz (per day consumption: $(8.88 \mathrm{kWh} /$ day).

Total electricity required as per day consumption is: $12.216 \mathrm{~kW} \mathrm{~h} /$ day

- 400 Gallons per day RO Unit can fill the 100 Gallons' storage tank 4 times.

- 4 times $/ 24 \mathrm{~h}$ will be $6 \mathrm{~h}$ per cycle to fill 100 Gallons. $6 \mathrm{~h}$ power consumption will be $3.054 \mathrm{~kW}$. Therefore 2 cycles $(200$ Gallons $)=6.108 \mathrm{~kW}(12 \mathrm{~h}$ daily $)$

-200 Gallons $/ 100$ residents $=2$ Gallons per person daily

The process of 11 water cisterns with one solar panel with electricity capacity of 12.216 /KW provides 400 Gallons water per day. Now if two solar panels were to apply on the site for 11 water cisterns, 800 Gallons $/ 3000 \mathrm{~L}$ water will be the outcome of this solution. As a result, $90000 \mathrm{~L}$ water per month can be provided. The required water of each individual person per month is approximately $50 \mathrm{~L}$. In this case, this filtration method is suitable for 1800 people. This amount is acceptable for assisting for portable water in Evaz city. In addition, this system can apply for southern regions in Iran, included north west of Hormozgan state and south east of Fars state as well since both states use the same water cistern system for their portable water use. Thus, it will be more suitable for the small city and villages with less than 5000 population. According to the statics, there are around 500 villages and small city located in this region. Therefore, this system can be updated to enhance the water cisterns to save peoples' lives for sustaining healthy portable water in this region [27].

\section{Solar panels}

To generate electricity for the water filtration device mentioned above, suitable solar panels are required. Two solar panels with capacity of $12.216 / \mathrm{kW}$ for each is essential in this part of the solutions [28-30].

Panels are used to power the load while charge controllers are used to control the charging of the batteries that will enhance the life of the batteries. Batteries are used to store charge and power the load when the sun is not shining (Fig. 26). 


\begin{tabular}{|c|c|c|c|c|}
\hline Quantity & Item & Description & Unit & Origin \\
\hline 13 & $\begin{array}{c}\text { Solar } \\
\text { modules }\end{array}$ & $\begin{array}{l}\text { DUSOL, DS72300, } 24 \mathrm{VDC}, 300 \mathrm{~W} \text {, poly-crystalline } \\
\text { cells with aluminum frame. }\end{array}$ & Nos & Dubai \\
\hline 1 & $\begin{array}{l}\text { Inverter/ } \\
\text { charger }\end{array}$ & $\begin{array}{l}\text { Schneider } 6048,48 \mathrm{~V} 6 \mathrm{KVA} \text { pure sine wave } \\
\text { inverter and charger }\end{array}$ & Nos & France \\
\hline 1 & $\begin{array}{l}\text { Charge } \\
\text { controller }\end{array}$ & $\begin{array}{l}\text { Schneider Mppt } 80-600,80 \mathrm{~A} 12 / 24 \mathrm{~V} \text { charge } \\
\text { controller } 600 \mathrm{~V} \text { maximum input from pv }\end{array}$ & Nos & France \\
\hline 24 & Battery & $\begin{array}{l}\text { Sunlight RES } 5 \text { SOPzS 605, 455Ah@C12,2V, } \\
\text { advanced Low Maintenance Tubular Plate Batteries } \\
\text { for Renewable Energy Storage }\end{array}$ & Nos & Greece \\
\hline 1 & Stand & $\begin{array}{l}\text { L3, and L10 Aluminum Mounting stand, for } \\
\text { mounting } 3 \text { panels per stand and } 10 \text { panels per stand } \\
\text { respectively with adjustable inclination }\end{array}$ & set & China \\
\hline 1 & $\begin{array}{l}\text { De junction } \\
\text { box }\end{array}$ & Dc junction box with busbar and fuses $f$ & Nos & Assorted \\
\hline 1 & cables & $\begin{array}{l}\text { Cables and connectors required for the installation } \\
\text { of the system }\end{array}$ & & India \\
\hline
\end{tabular}

Fig. 30. Specification of the solar panel and the devices [32].

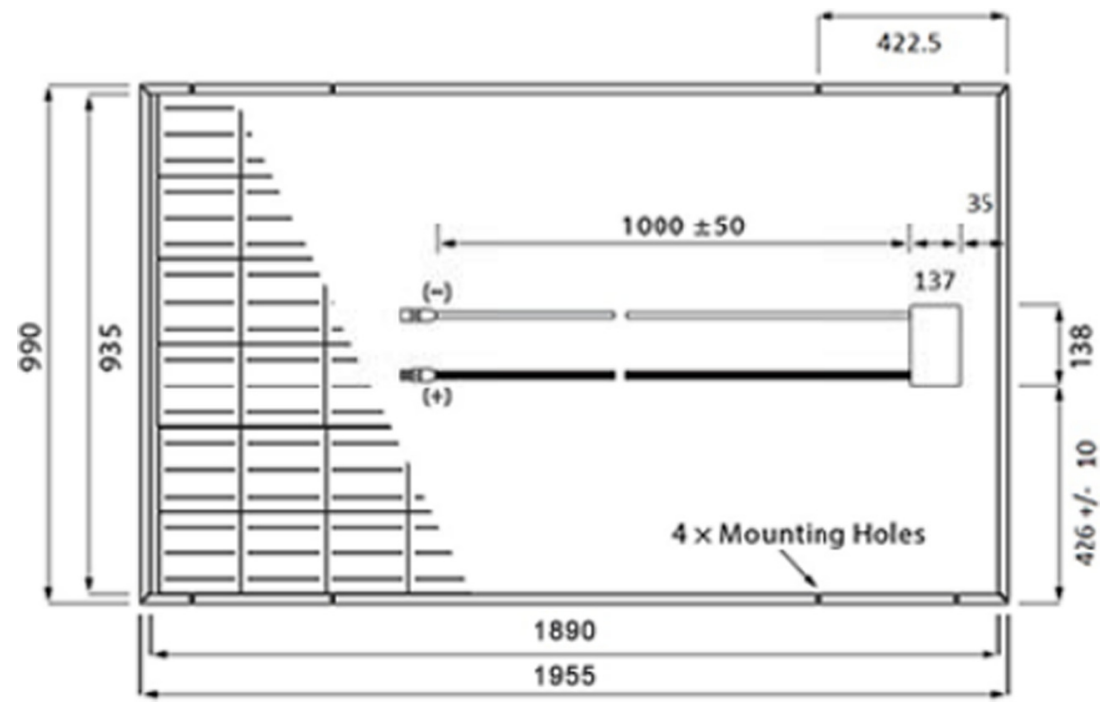

Fig. 31. Dimension of the solar panel, apex solar company [32].

The batteries are designed to operate for 1 day of no-sun back up. An inverter is provided to convert DC power form the battery to $\mathrm{AC}$ power so that the loads can be operated. Cables and connectors are provided to wire the system completely. A solar mounting stand is provided to place the panels. Because of the dome shape in water cistern, it has been decided to design the solar panels in with the dome shape to fit on. After analyzing both quotations for two different panels, there was a huge price difference. Therefore, the decision was to choose the normal shape of solar panel, the specification of the panel as shown in Figure 30 [31].
In the dome shape solar panel design, water cistern looks more beautiful but the price increases a lot. In the city similar to Evaz, investing for this amount of money needs management that is more precise. With the experience of attending some of the cultural and city development meetings of Evaz city, it has been discovered that Evazi people are interested to inv est and develop their small city of less natural resources. Although this proof of concept is looking beautiful and useable, the cost is not reasonable since it will cost around 400000 Dirhams. Therefore, the second option provides similar process and good amount of power to filtrate the water for peoples' daily water use [31]. 
Characteristic curves: Current / power against voltage (cell temperature: $25^{\circ} \mathrm{C}$ )

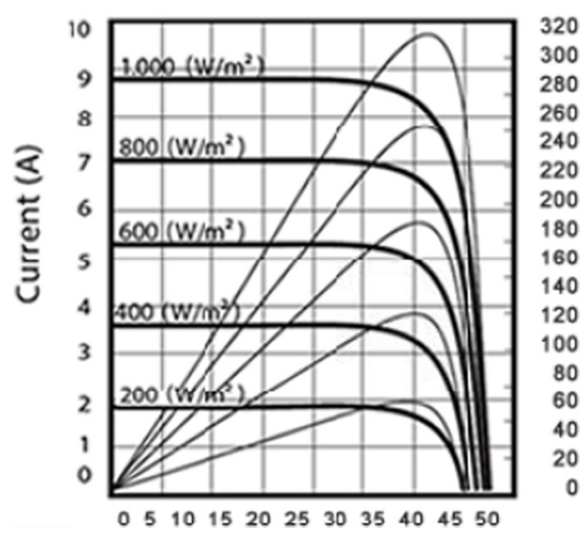

$\mathrm{X}$-axis $="$ Voltage $(\mathrm{V})^{\prime \prime}$

Fig. 32. Characteristics of the solar panel [32].

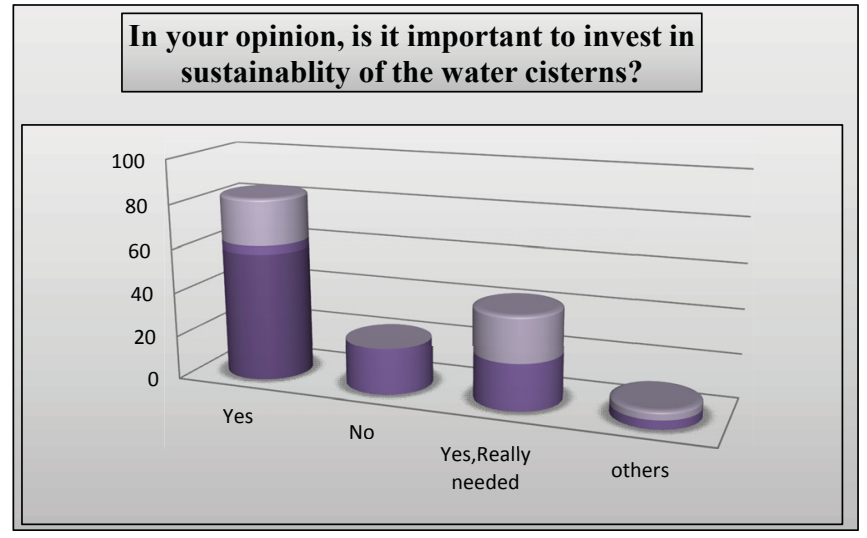

Fig. 33. Graph bar shows people's opinion for investing on water cistern.

On the other hand, it is not necessary to install the Photovoltaic (PV) panels on top of the cistern, instead to install them close by, e.g. streetlights. Therefore, the latter option, accordingly with health and safety regulations, helps to improve the conditions in the area without any obstructions (Figs. 27-29).

The details and specification of the devices, which are connected to the solar panels are shown below (Fig. 30) [27].

The dimension of the solar panel is $990 \times 1955$ from the outline and $935 \times 1890$ from the inside (Fig. 31).

The selected solar panel has 72 cells from polycrystalline $3 \mathrm{BB}$ (Bus Bar) cells with the size of $156.5 \times 156.5 \mathrm{~mm}$. The front glass is made of tempered low iron pattern glass with $4 \mathrm{~mm}$ thickness. The frame of the solar panel is made from anodized aluminum silver (Figs. 32 and 33) [32].

\section{Cost benefits analysis}

In Evaz, due to the water shortage, supplies are limited. Most of the time, people are obligated to buy additional water to meet their needs. However, people are spending money for drinking water as urban water is not drinkable, and therefore investing in the water cisterns will be essential for sustainability in the city. Water cisterns are supporting people for their daily requirements. In this case, people agree to invest in such resources and benefit from the water cisterns, which has been considerably helpful since 1250 BC. The graph in Figure 17 shows Evaz citizens' opinion about spending on and investing in the water cisterns, and whether this is required or not.

As presented in Figure 17, Evazi citizens' opinion on investing in sustainability of the water cisterns; $58 \%$ of the people are come to an understanding with investing in the innovation of water cisterns although $4 \%$ do not think this is a requirement. Meanwhile, $21 \%$ of the people mentioned that it is really needed. In addition, $4 \%$ wrote their opinion about investing into the water cisterns, and an individual mentioned since there are no updated systems to resolve the water issues, this can be a respectable innovation for any future use. Another individual mentioned that investing into the water cisterns is essential for both sustainably and utilization of the water cistern. The last opinion came from a person who believes urban water is not $100 \%$ safe, means the water cisterns needs to be updated and integrated for more efficient use.

In summary, most of the people (95\%) believes that spending and investing for the water cisterns is required for today's needs. In addition, there should be a solution, which can cover the issues of the water cisterns for today and hence in the future. On the other hand, when sustainability of the ancient structure is required, there will be some additional expenses to pay for assisting of durability of the building [22,33-36]. Nowadays, building a new water cistern is expensive and not everyone is willing to pay for this.

Therefore, it is important to create an innovative system for durability of the structure especially when it's a vital substance of humans need. The ancient structure is valuable in all countries, here in Evaz, this structure is not only an old and historical part of the citizen's life, but also plays a big role of intelligent passive structure to meet the peoples' need without processing and any requirement of electricity or additional energy resource [37-39]. In fact, with investing and updating today's water cistern will be a 


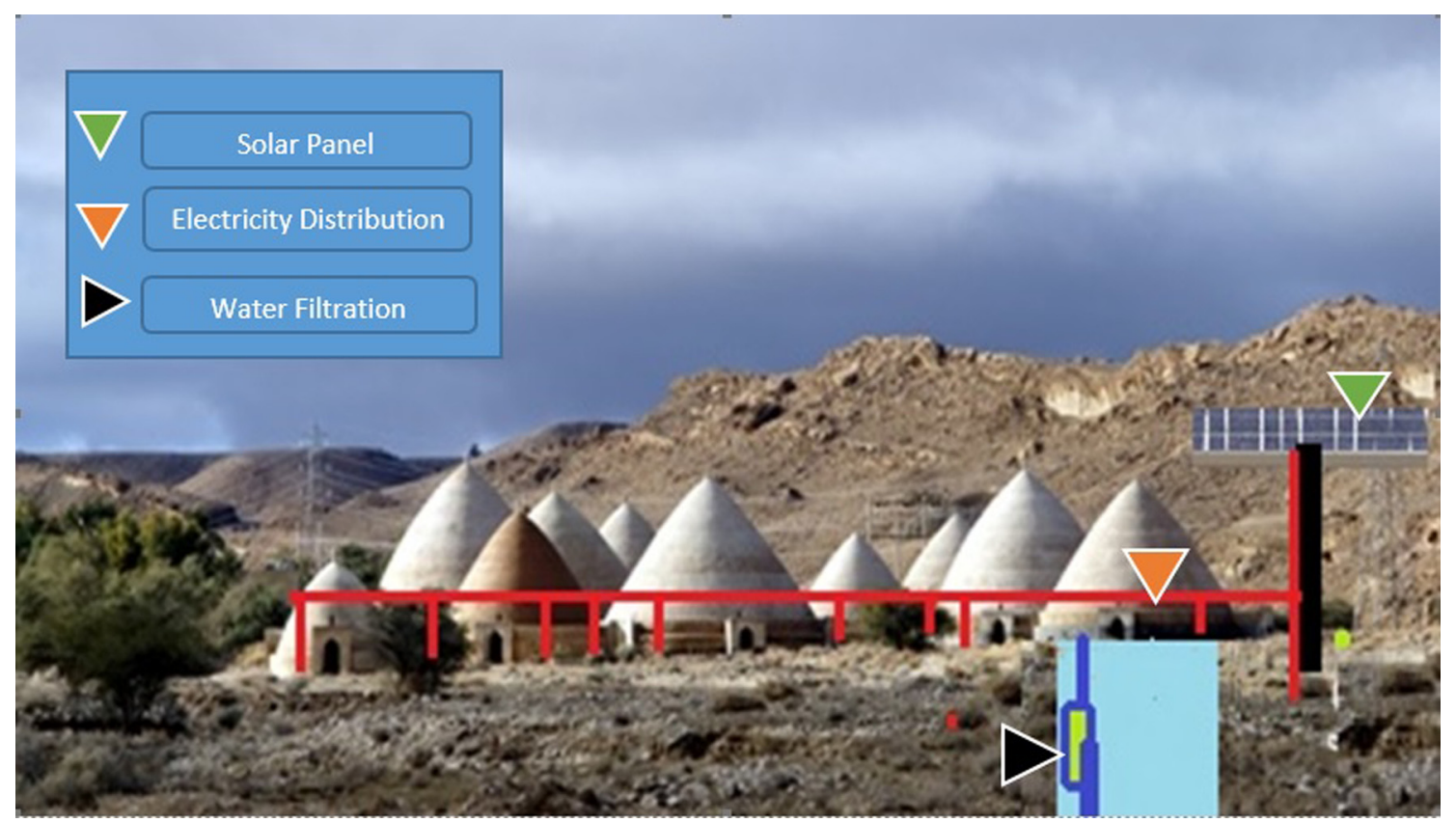

Fig. 34. Process of filtering machine inside the water cistern, proof of concept.

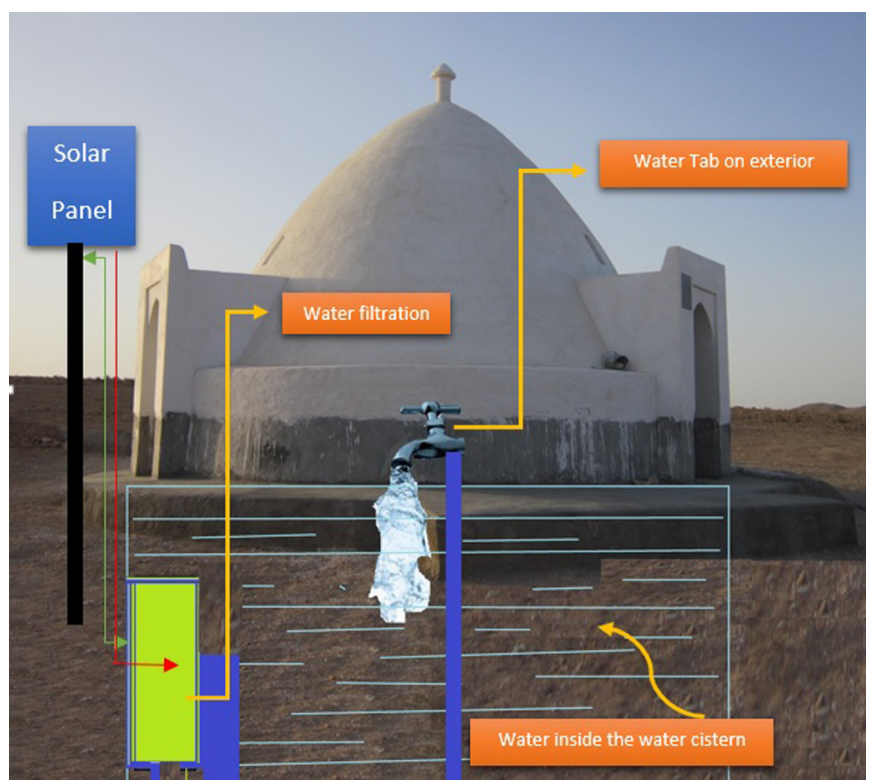

Fig. 35. Process and the piping inside the water cistern, proof of concept.

great idea to help save and sustain for many years. Although the age of these water cisterns are more than 700-800 years old, it is necessary to update them after some years to make them not only to last longer, but also to help people continue to use them efficiently by sustaining their living in the region towards a sustainable future.

Again, the graph shows the opinion of the people in Evaz (Fig. 17), according to durability of the water cistern in today's situation. As can be seen from the given illustration, $72 \%$ of the people believe that durability of the water system is depending on how people use them.
Although $4 \%$ believes that it will not be available any more if they are continued to be used this way. Merely, $18 \%$ said it is going to stay for long time. The percentage of people who believes the water cistern will not sustain in this way for the future is higher than the people who believes this well remain the same for upcoming use.

In summary, a few people believe the durability and sustainability in today's condition will be sustain for the future. Therefore, the results have shown that the water cisterns need to be updated in a sustainable way. This matter is vital for human's life for Evaz otherwise in the future with the conditions of global warming and changes in nature and rainfall, a big problem will arise concerning drinking water and the amount of water for daily uses at residential and commercial places.

Building a new water cistern with a standard or normal size today will cost around 100000-150000 Dirham. If a new water cistern to be built, it will come with a high cost as long as modifications and reuse of numbers of 11 water cistern with $12.216 \mathrm{~kW}$ load for $12 \mathrm{~h}$ with 1 day autonomy, which is costing around 68000 Dirham. In this case, investing in water cistern modification is a smart move and a great deal. This method can save them for the future not only as an ancient structure, but also as a part of vital life [40].

As a result of the survey, which is based on Evaz citizens' opinion and their needs for water resources, the water cisterns system should be updated to remain in use and sustain human's life in the future (Fig. 34).

In addition, there were some other issues in the water cisterns with proposed solutions through observations:

One of the main issues is pollution through animals entering the water cistern to drink water and end up falling into it. Therefore, it is important to have a metal door, which can be open easily by people (Fig. 35). 


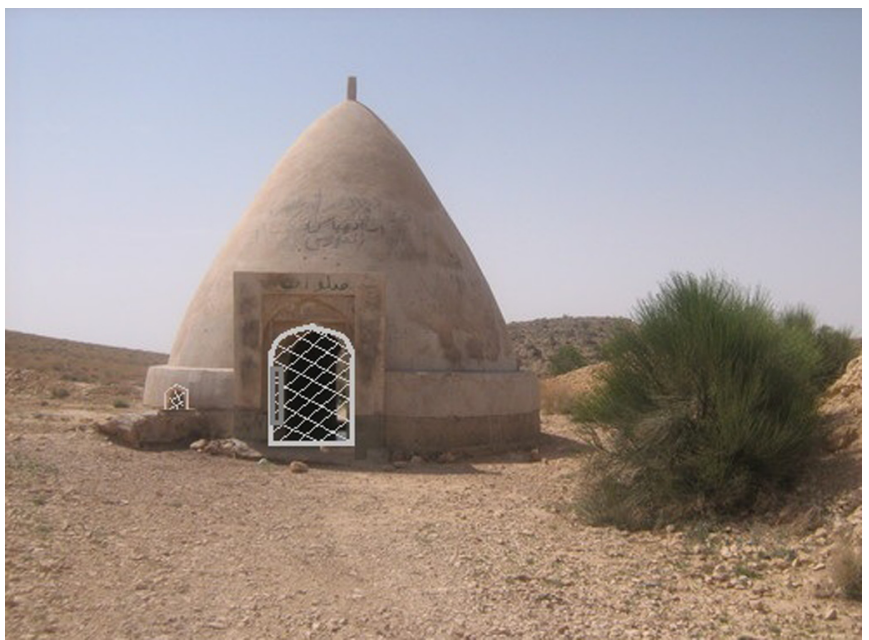

Fig. 36. Avoiding entering animals to water cisterns, proof of concept.

In addition, installing a metal door will not be costly and it can assist the water cistern system to stay more clean, and be more useful for human's need. The other advantage of adding a door is that it will not destroy the shape of the water cistern but rather help to stop most animals enter inside. On the other hand, the heritage look of the water cistern will stay the same and continue to be usable (Fig. 36).

Another solution is offered for the transportation process. People used to collect water by carrying it in a bucket after filling it up from the water cistern. This process can be used today as well but for people who are not able to do so or do not have the power to hold a heavy bucket, there is another solution, which can be offered that is not costly, and in fact, much practical. By adding the pipes and machines inside the water cistern, adding an extra pipe with tab is not a big deal to make the process of collecting water from the water cistern easier and without any difficulties, this part can be connected to the filtration tank as well (Fig. 35). In this case, any traveler who is passing by this city can collect the water for drinking easy. In the other hand, transporting water by tank for resident $\mathrm{s}$ will be easier too.

After the solutions are applied, the situation will be different, water is clean and the process of collecting water is much easier with only small changes, which will not affect the outlook of the water cistern, and also will make peoples' life easier. In addition, it will extend the use and life span of the water cisterns. Most of the studies that were undertaken on similar projects were costly and required high power as well as the government's help to resolve the issues. However, by these solutions, any citizen can resolve the problem and assist with sustainability of the water cisterns and human's life in the region.

\section{Maintenance and safety}

In view of the fact that there are no moving elements in solar panels, they do not require expensive maintenance; only a short period of time in a year, the panels have to be looked after for whichever grime or wreckage that might

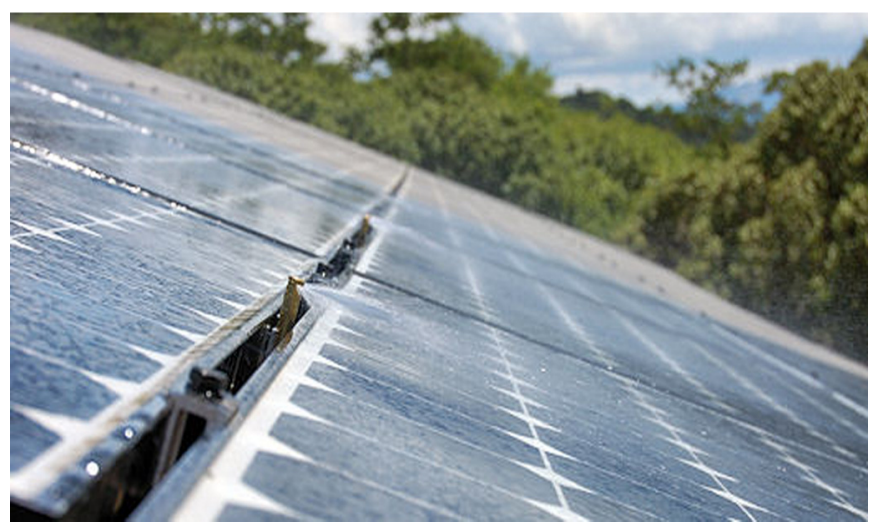

Fig. 37. Automatic system of maintenance for solar panel [41].

assemble on them. Therefore, after installing the panels, the maintenance will not be hard to manage. Somehow bringing a new system in town can help people to add their knowledge, and meet their satisfaction. In addition, it can create jobs for people as well, since Evaz's population is small and small number of jobs are available for the applicants. In fact, this kind of solar panels can be used for electricity generation for the residents' living. Also, as long as Evaz is facing electricity issues for its residents annually and especially during summers, where the weather conditions are hot and the electricity consumption is high due to their air conditioning needs, this will help meet such a demand. Shortage of electricity in summer is another issue Evaz's citizens are facing, which can be resolved with the same solution; installing PV panels. Therefore, it is a great opportunity to start solving such issues by renewable energy resources.

Location of the solar panel is going to be close to the water cistern and placed above it, and therefore, people cannot have easy access to it. The weather conditions in Evaz could help since there is limited rain and snow, solar panels can last longer.

Nowadays automated cleaners are available, which works with sprinklers. It has to be programmed first then it can automatically clean the panels without any human interaction. It is moreover a great idea if the weather conditions are dusty. [41] (Fig. 37).

\section{Discussion, conclusion and recommendations}

The issue of the natural disasters and climate change in the world has been strongly effected on the water requirements of the people in Iran. As a first step, the amount of rain during a year and how much water can be stored from this have been identified in Evaz city. After this, similar projects with focus on rain harvesting methods and filtering water for daily usage was introduced although for Evaz project the focus is on the portable water not just water for daily usage.

After analysing the importance of water cisterns and the value of it for Evaz's citizens, the result has come up that the issues of the water cistern has to be resolved in the 


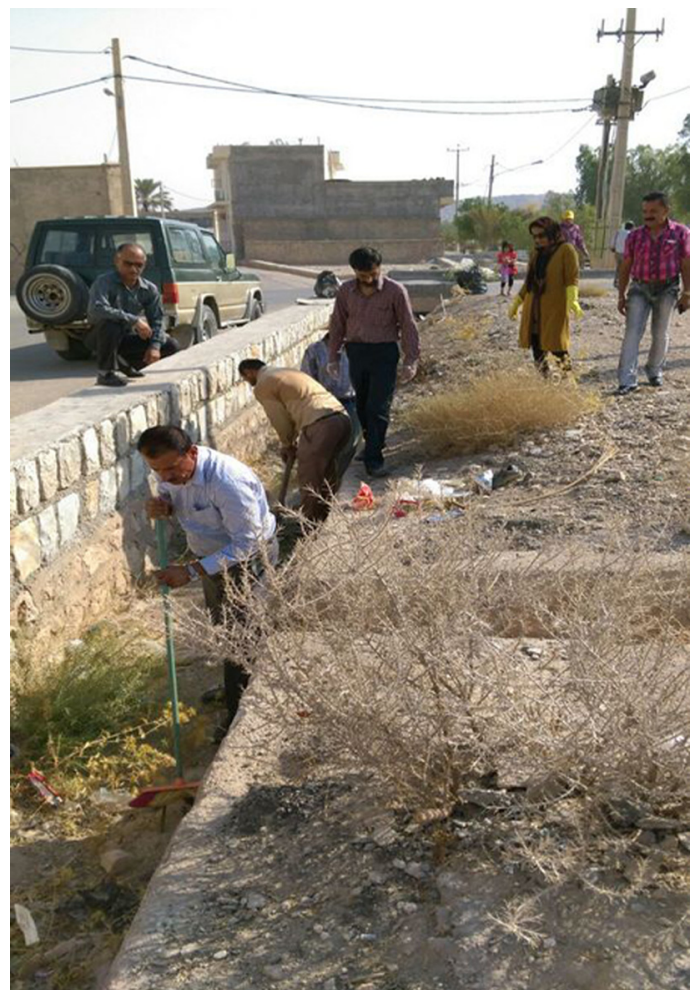

Fig. 38. Local people cleaning the pathway of rain [44].

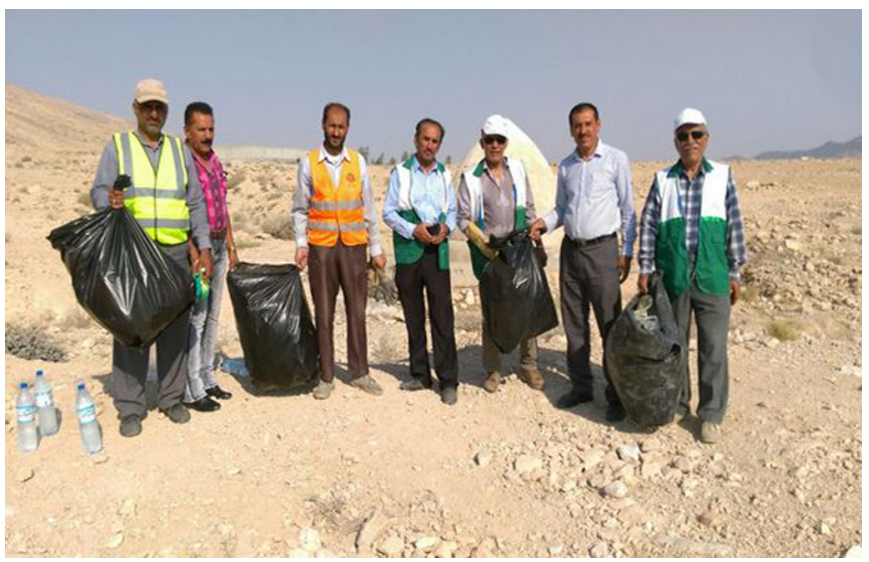

Fig. 39. Local people cleaning the pathway of rain [45].

earliest time to be able to save water for vital need and daily requirements. The aim of this study was to find out the problems and solutions for the lack of the water problem in south of Iran by assistance of vernacular architecture and sustainable solutions.

After the collection of required data, solutions became focus of the study in order to save the captures of the rain water and use as portable water. By the solar panel electricity could be generated and $250000 \mathrm{~L}$ of rain water can be saved and provided for people with filtration devices, which can work $24 \mathrm{~h}$ per day. Moreover, this solution/system can be applied not only in Evaz, in fact in most of the small cities and villages around it due to the fact that they have the same water cisterns with a bit of different look as well.

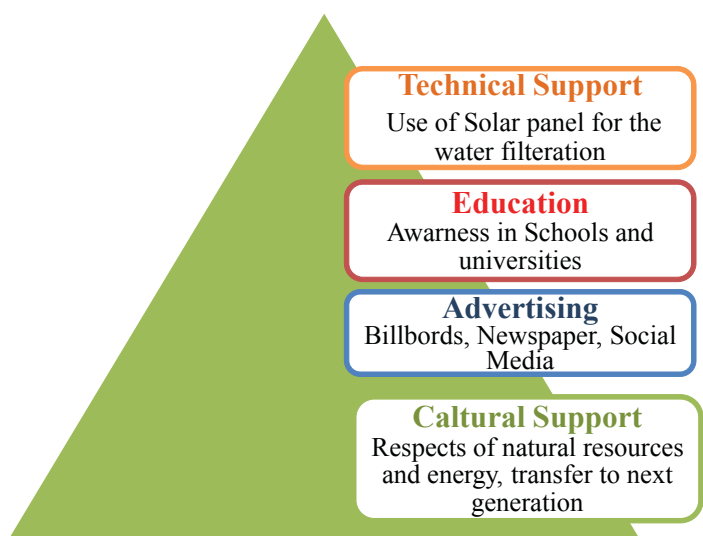

Fig. 40. The main four sections for sustainable environment in Evaz city.

Water cistern as a most important element of this region is evaluated. For purifying and creating best method and design, sustainable solutions have been provided by facilitating the solar energy for the purpose of filtration method to refine the water and prepare it for drinking. South of Iran has a strong power of solar energy which can be very beneficial for obtaining power to use for this process. In addition, new ideas have been advised to support the ancient shape of water cistern. Idea of the metal door is given as well to avoid entering any animal or wastage inside the water cistern. The idea of using solar panel is going to be cost effective at this time, while using one solar panel can have the power to filter 10 water cistern, which is equal to building one new water cistern. In this case, of sustainable solutions, all the matters should be considered carefully and precisely. Especially when the product's cost is high. In the first stage, designer should consider who is going to pay for the product and how it is going to help the city and the people's life style.

Evaz had built universities, schools and hospitals on the support of the people and they are highly looking forward to improve the city. Therefore, applying this solution is not far from what has been suggested and proposed within this paper with the support of this study. Some related research has already shown the benefits can be achieved from applications of solar panels; how effective solar panels can be and extensive amount of electricity that can be generated from the sun, because of Iran's geographical position and the gaining amount in solar radiation. Therefore, the considerable amount in cost and energy can be saved for the future of the Evaz city in Iran [31].

In addition, from economical aspect, this idea will provide more job opportunities [9]. According to Evaz population, the lack of job is also an economical issue in this city. Therefore, creating new jobs related to the highest technology and efforts will be a great idea to improve the economic and educational level of residents' life. Spending for water cistern to save water and have better resources of clean and pure water is an investment for the near future especially the base of the source is natural energy, which is completely free. An example from similar projects shows two different type of jobs will be created, Direct and indirect jobs, which are all related to proposed solution for 
the water cisterns. Also, people will be required less than before to buy water for their drinking and daily requirements.

These kinds of cases are not only sustainable solutions it's also cultural and educational as well. Therefore, perception of the citizens is helpful and considerable in this topic. While the water cisterns are located outside and inside the city both, people are communicating or passing those areas daily, they are very familiar with its processes and also aware of the value of it. In addition, it is comprehensible for them to know how much they have to care about it to save the water and the vernacular structure for today's and tomorrow's generation as well. Nowadays most of the authorities are trying to motivate people to save the water and respect the environment more than before. They are trying to motivate people through social media to keep the city clean specially during rainy days, clean up the pathway which water gets in and from that side will enter to the water cistern. The good news is people has accepted the issue and they do not hesitate to do anything to save the environment and human's life, which is connected to the water (Figs. 38 and 39).

The recommendations are divided in four categories to save the water and water cisterns. Accordingly, saving water cisterns and water is not an easy task (Fig. 40). All of these four sections should work strongly. The weakness in each of these sections may have an impact on the sustainability and durability of the city's water cisterns.

\section{References}

1. S. Inc., The vernacular architecture as a model for sustainable design in Africa (2016), Available at: https://www.scribd. com/doc/33702709/ (last consulted on: 2016/07/09)

2. M.A. Kamal, The morphology of traditional architecture of Jeddah: climatic design and environmental sustainability, Global Built Environ. Rev. 9, 4 (2014), Available at: http:/ www.globalbuiltenvironmentreview.co.uk/Documents/9.1\% 20commentary\%20Arif\%20Kamal.pdf (last consulted on: 2016/20/08)

3. M. Masrour, M. Karbaschi, Comprehending vernacular architecture in the architectural educational system in Iran, Am. J. Civil Eng. Archit. 3, 45 (2015), DOI:10.12691/ajcea3-2-2, Available at: http://pubs.sciepub.com/ajcea/3/2/2/ (last consulted on: 2016/20/08)

4. M.K. Singh, S. Mahapatra, S.K. Atreya, Solar passive features in vernacular architecture of north-east India, Solar Energy 85, 2011 (2011), DOI:10.1016/j.solener.2011.05.009, Available at: http://orbi.ulg.ac.be/handle/2268/129725 (last consulted on: 2016/20/05)

5. Z. Zhai, J.M. Previtali, Ancient vernacular architecture: characteristics categorization and energy performance evaluation, Energy Build. 42, 357 (2010), Available at: http:// www.ucdenver.edu/academics/colleges/Engineering/re search/CenterSustainableUrbanInfrastructure/LowCar bonCities/Documents/Zhai/Zhai_AncientVen.pdf (last consulted on: $2016 / 20 / 08$ )

6. Islamic Azad University (IAU), History of Evaz information (2015), Available at: http://www.iauevaz.ac.ir/?page id= 366 (last consulted on: 2016/02/06)
7. N. Valibeig, H.M. Isfahani, Desert water cisterns, the symbol of sustainable structures in Iranian architecture, Cumhur. Sci. J. 36, 582 (2015), DOI:10.17776/csj.29906, Available at: http://dergi.cumhuriyet.edu.tr/cumuscij/article/view/ 5000121898 (last consulted on: 2016/07/09)

8. R. Breiner, T. Heid, H.S. Müller, Development of an appropriate mortar for sustainable rain water cisterns, Procedia Eng. 95, 396 (2014), DOI:10.1016/j.proeng.2014.12.198, Available at: http://www.sciencedirect.com/science/article/pii/ S1877705814032573 (last consulted on: 2016/02/09)

9. M. Çetin, N. Egrican, Author info, Energy Policy 39, 7184 (2011), Available at: https://www.researchgate.net/publica tion/241091050 Employment impacts of solar ener gy_in_Turkey (last consulted on: 2016/20/05)

10. X. $\bar{C}$ hen, H. Yang, L. Lu, A comprehensive review on passive design approaches in green building rating tools, Renew. Sustain. Energy Rev. 50, 1425 (2016), DOI:10.1016/j. rser.2015.06.003, Available at: http://www.sciencedirect. com/science/article/pii/S1364032115005730 (last consulted on: 2016/03/09)

11. D. Dan, C. Tanasa, V. Stoian, S. Brata, N.T. Gyorgy, S.C. Florut, Passive house design - an efficient solution for residential buildings in Romania, Energy Sustain. Dev. 32, 99 (2016), DOI:10.1016/j.esd.2016.03.007, Available at: http:// www.sciencedirect.com/science/article/pii/ S0973082615301629 (last consulted on: 2016/02/09)

12. H. Kamal, Study of the effects of the history and art of City of Evaz (Suburban and in Town): historical and artistic effects of Evaz, Iran (Suburban and in Town) (Navid Publication, Shiraz, 2005)

13. M.K. Pirnia, Architecture Styles of Houses in South of Iran (Evaz), Methods of Iranian Architecture, 5th ed. (Soroshe Danesh Publication, Iran, 1990)

14. M.H. Karamati, History of Pleasing Evaz, Vernacular Architecture (Navid Shiraz Publication, Shiraz, 1953)

15. EPNU, Geographical background of Evaz, geographical position and reason of the weather, population of Evaz city, current population of Evaz (2010), Available at: http:// www.epnu.ir/ (last consulted on: 2016/02/05)

16. SEEIRAN, Holes around the cistern, Evaz, Iran (2011), Available at: http://seeiran.ir/ (last consulted on: 2016/25/06)

17. H. Seddighi, Mulla Mohammad water cistern (2012), Available at: http://www.evaz-shahrdari.ir (last consulted on: $2016 / 10 / 07$ )

18. P.W. English, Qanats and lifeworlds in Iranian plateau villages (1998), Available at: http://environment.yale.edu/ publication-series/documents/downloads/0-9/103english. pdf (last consulted on: 2016/07/09)

19. Shefaee, Ardeshir, Zeinalabedin, Graph of 16 years' rainfall in Evaz (2015), Available at: http://awazemrooz.ir (last consulted on: 2016/09/11)

20. L.A. Wooten, Evolution of water quality parameter (Enterococcus spp., total suspended solid and specific conductance) in harvested rainwater and simplification for management and use (2015), Available at: http://search.proquest.com. ezproxy.buid.ac.ae/docview/1727614209/6B70BE84E6F F4FBAPQ/1?accountid=178112 (last consulted on: 2016 / $22 / 11)$

21. N. Pelak, A. Porporato, Sizing a rainwater harvesting cistern by minimizing costs, J. Hydrol. 541, 1340 (2016), DOI:10.1016/j.jhydrol.2016.08.036, Available at: http:// www.sciencedirect.com/science/article/pii/ S0022169416305261 (last consulted on: 2016/02/08) 
22. C.B. Kulkarni, Design, evaluation and techno-economic analysis of a hybrid solar-wind power generation system in UAE (2011), Available at: http://bspace.buid.ac.ae/handle/ 1234/128 (last consulted on: 2016/25/08)

23. A. Kumar, G. Pushplata, Vernacular practices: as a basis for formulating building regulations for hilly areas, Int. J. Sustain. Built Environ. 2, 183 (2013), DOI:10.1016/j. ijsbe.2014.01.001, Available at: http://www.sciencedirect. com/science/article/pii/S2212609014000107 (last consulted on: $2016 / 20 / 08)$

24. Y.S. Lim, C.K. Lo, S.Y. Kee, H.T. Ewe, A.R. Faidz, Design and evaluation of passive concentrator and reflector systems for bifacial solar panel on a highly cloudy region - a case study in Malaysia, Renew. Energy 63, 415-425 (2014), DOI:10.1016/j.renene.2013.10.008, Available at: http:// www.sciencedirect.com/science/article/pii/ S0960148113005387 (last consulted on: 2016/10/08)

25. R.T.A. Prado, D.S. Sowmy, 7 - innovations in passive solar water heating systems, Adv. Solar Heat. Cool. 117 (2016), DOI:10.1016/B978-0-08-100301-5.00007-2, Available at: http://www.sciencedirect.com/science/article/pii/ B9780081003015000072 (last consulted on: 2016/10/08)

26. A. Saeidian, Sustainable traditional water supply system in hot arid regions, remarkable example of Iranian vernacular architecture (2013), Available at: http://www.elixirpublish ers.com/articles/1363859589 56A\%20\%282013\%29\% 2013584-13590.pdf (last consulted on: 2016/07/09)

27. F. Tescon, Water filtration producer, Dubai, UAE (2016), Available at: http://www.ultratec-uae.com/ (last consulted on: $2016 / 20 / 06)$

28. A.F. Hadi, The potential of integrating PV in the heritage sites case study of Dubai museum (2015), Available at: http://bspace.buid.ac.ae/handle/1234/736 (last consulted on: $2016 / 25 / 05)$

29. S. Ferrari, M. Lazzaroni, V. Piuri, A. Salman, L. Cristaldi, M. Faifer, S. Toscani, Solar panel modelling through computational intelligence techniques, Measurement 93, 572-580 (2016), DOI:10.1016/j.measurement.2016.07.032, Available at: http://www.sciencedirect.com/science/article/pii/ S026322411630392X (last consulted on: 2016/02/09)

30. Gaia, Solar energy and the environment (2016), Available at: http://environment-ecology.com/energy-and-environment/ 99-solar-energy-and-the-environment.html (last consulted on $2016 / 07 / 09)$

31. F. Mirahmadi, H. Altan, Vernacular architecture of south of Iran, Evaz (2015), Available at: http://zemch2015.unisa lento.it/images/doc/ZEMCH_PROCEEDING_V5.pdf (last consulted on: 2016/15/06)

32. APC, DUSOL PV modules, PV design for specific element, apex power concepts (2015), Available at: http://www. apexpowerconcepts.com/ (last consulted on: 2016/02/05)
33. G. Goldman, Environmental impacts of solar power (2016), Available at: http://www.ucsusa.org/clean_energy/our-en ergy-choices/renewable-energy/environmental-impacts-so lar-power.html\#.V9BubyfN3Gc (last consulted on: 2016/ $07 / 09)$

34. Impact of Solar Energy on the Environment (2015), Available at: http://www.greenmatch.co.uk/blog/2015/01 (last consulted on: 2016/07/09)

35. D. Media, Positive \& negative effects of solar energy, Available at: http://homeguides.sfgate.com/positive-nega tive-effects-solar-energy-79619.html (last consulted on: 2016/07/09)

36. T. Tsoutsos, N. Frantzeskaki, V. Gekas, Environmental impacts from the solar energy technologies, Energy Policy 33, 289 (2005), DOI:10.1016/s0301-4215(03)00241-6, Available at: http://www.circleofblue.org/wp-content/uploads/ 2010/08/Tsoutsos_Frantzeskaki_2006_EIA_ST.pdf (last consulted on: 2016/07/09)

37. Q. Roslan, S.H. Ibrahim, R. Affandi, M.N.M. Nawi, A. Baharun, A literature review on the improvement strategies of passive design for the roofing system of the modern house in a hot and humid climate region, Front. Archit. Res. 5, 126 (2016), DOI:10.1016/j.foar.2015.10.002, Available at: http://www.sciencedirect.com/science/article/pii/ S2095263515000564 (last consulted on: 2016/02/09)

38. H.N. Rostvik, Listed church buildings and solar energy, J. Archit. Conserv. 19, 49 (2013), DOI:10.1080/ 13556207.2013.787019, Available at: http://www.tandfon line.com/doi/abs/10.1080/13556207.2013.787019 (last consulted on: $2016 / 20 / 08)$

39. J. Sadeghsaberi, S. Zarei, S.O. Hemmati, M. Kameli, Passive solar building design, J. Novel Appl. Sci. 2, 1178-1188 (2013) Available at: http://jnasci.org/wp-content/uploads/2013/ 12/1178-1188.pdf (last consulted on: 2016/25/09)

40. A. Khadempour, Architecture Department in Evaz (2016)

41. Solar Panel Maintenance the Solar Company (2016), Available at: http://www.thesolarco.com/solar-energy/so lar-panels/solar-panel-maintenance/ (last consulted on: 2016/02/08)

42. M.A. Nobahar, Architecture of courtyard in south of Iran (2015), Available at: http://gerash.info/post/124

43. Geomodel Solar, Average annual sun of Iran. Situation of solar radiation power in Iran (1999-2011), Available at: http://solargis.info/doc/_pics/freemaps/1000px/ghi/ SolarGIS-Solar-map-Iran-en.png (last consulted on: 2016/ 08/05)

44. A. Rahimi, Cleaning pathways (2016), Available at: http:// www.ewazstars.com (last consulted on: 2016/25/06)

45. M. Rahimi, Water cistern photography (2016), Available at: http://www.ewazstars.com (last consulted on: 2016/ $25 / 06)$

Cite this article as: F. Mirahmadi and H. Altan: A solution for future designs using techniques from vernacular architecture in southern Iran. Sust. Build. 3, 1 (2018). 